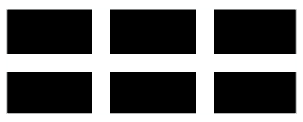

The WiLliam DAVIDSON Institute AT THE UNIVERSITY OF MICHIGAN BUSINESS SCHOOL

\title{
A Minimum of Rivalry: Evidence from Transition Economies on the Importance of Competition for Innovation and Growth
}

By: Wendy Carlin, Mark Schaffer and Paul Seabright

William Davidson Institute Working Paper Number 670 May 2004 


\title{
A minimum of rivalry: evidence from transition economies on the importance of competition for innovation and growth
}

\author{
Wendy Carlin, University College London, CEPR and WDI \\ Mark Schaffer, Heriot-Watt University, CEPR and WDI \\ Paul Seabright, IDEI (Université de Toulouse-1) and CEPR
}

March 2004

\begin{abstract}
This paper examines the importance of competition in the growth and development of firms. We make use of the large-scale natural experiment of the shift from an economic system without competition to a market economy to shed light on the factors that influence innovation by firms and their subsequent growth. Using a dataset from a survey of nearly 4,000 firms in 24 transition countries, we find evidence of the importance of a minimum of rivalry in both innovation and growth: the presence of at least a few competitors is effective both directly and through improving the efficiency with which the rents from market power in product markets are utilised to undertake innovation.
\end{abstract}

Keywords: competition, productivity growth, innovation, rivalry, transition

Journal of Economic Literature Classification Numbers: P0, L1, L33, O12

Corresponding author:

Wendy Carlin, Department of Economics, University College London, Gower St, London WC1E 6BT. email: w.carlin@ucl.ac.uk

\footnotetext{
${ }^{1}$ We have received advice and help from Philippe Aghion, Richard Blundell, Ronald Braeutigam, Saul Estrin, Rachel Griffith and Mark Schankerman. We are grateful to the EBRD and World Bank, who financed the survey, and especially to Steven Fries, with whom we have co-authored related papers using these data. The usual caveat applies.
} 


\section{Introduction}

How much does competition matter for the growth and development of firms, and if it is significant, through what channels does it work? These are important and long-standing questions in economics, but ones to which convincing answers have been frustratingly difficult to find. Theories of the influence of competition on firm behaviour and performance suggest that this influence can work through many different channels, some of them mutually offsetting, so the question of their relative importance can only be settled empirically. However, there are many obstacles in the way of finding convincing empirical answers. These consist partly in the lack of appropriate data, notably concerning measures of the competitive pressure faced by firms. Proxies such as shares of administratively defined product markets identified by SIC codes may be a long way from identifying the true nature of economic competition. The obstacles consist partly also in the difficulty of identifying the appropriate counterfactual against which actual outcomes can be measured. When the degree of competition varies many other things typically vary as well, including technology and regulation, and it is not easy to see which of these variations should properly be considered exogenous to the economic processes under investigation.

In this paper we present evidence that competition matters for firm innovation and growth. Specifically, we find evidence that firms facing just a few rivals perform better than those that face none; there is also some less clear-cut evidence that the presence of a few rivals is more conducive to performance than the presence of many competitors. This is consistent with a broadly Schumpeterian view of the relationship between competition and performance (such as has begun attracting renewed theoretical interest in recent years).

In the raw data presented in Fig. 1, there is a clear inverted-U relationship between firm growth and the number of competitors faced by the firm. Firms facing between one and three competitors had average sales growth of nearly $11 \%$ over the three years to 1999 , while monopolists saw real sales decline by over $1 \%$ and firms facing more than three competitors had sales growth of under $2 \% .{ }^{2}$ To investigate whether this bivariate correlation stands up to more rigorous econometric estimation is the task of this paper. We also explore in some detail the channels through which competition works, distinguishing between the effects of

\footnotetext{
${ }^{2}$ The vertical lines are $95 \%$ confidence intervals from a simple least squares regression of log sales growth on three category dummies (monopolist, 1-3 competitors, $>3$ competitors) and no constant.
} 
competition on managerial and work-force motivation, and its effects on the resources available to firms to put into practice their strategies of investment and innovation. We do so in two ways. First of all, we use two measures of competitive pressure, one being the number of rival firms perceived by the firm in its main market, and the other being the elasticity of demand the firm perceives for its products; these turn out to have distinct and largely independent influences on firm behaviour. In turn we look at this behaviour in two ways through measures of the innovation activity undertaken by the firm, and through a measure of its growth in sales. These respond in distinct ways to the two kinds of competitive pressure just described.

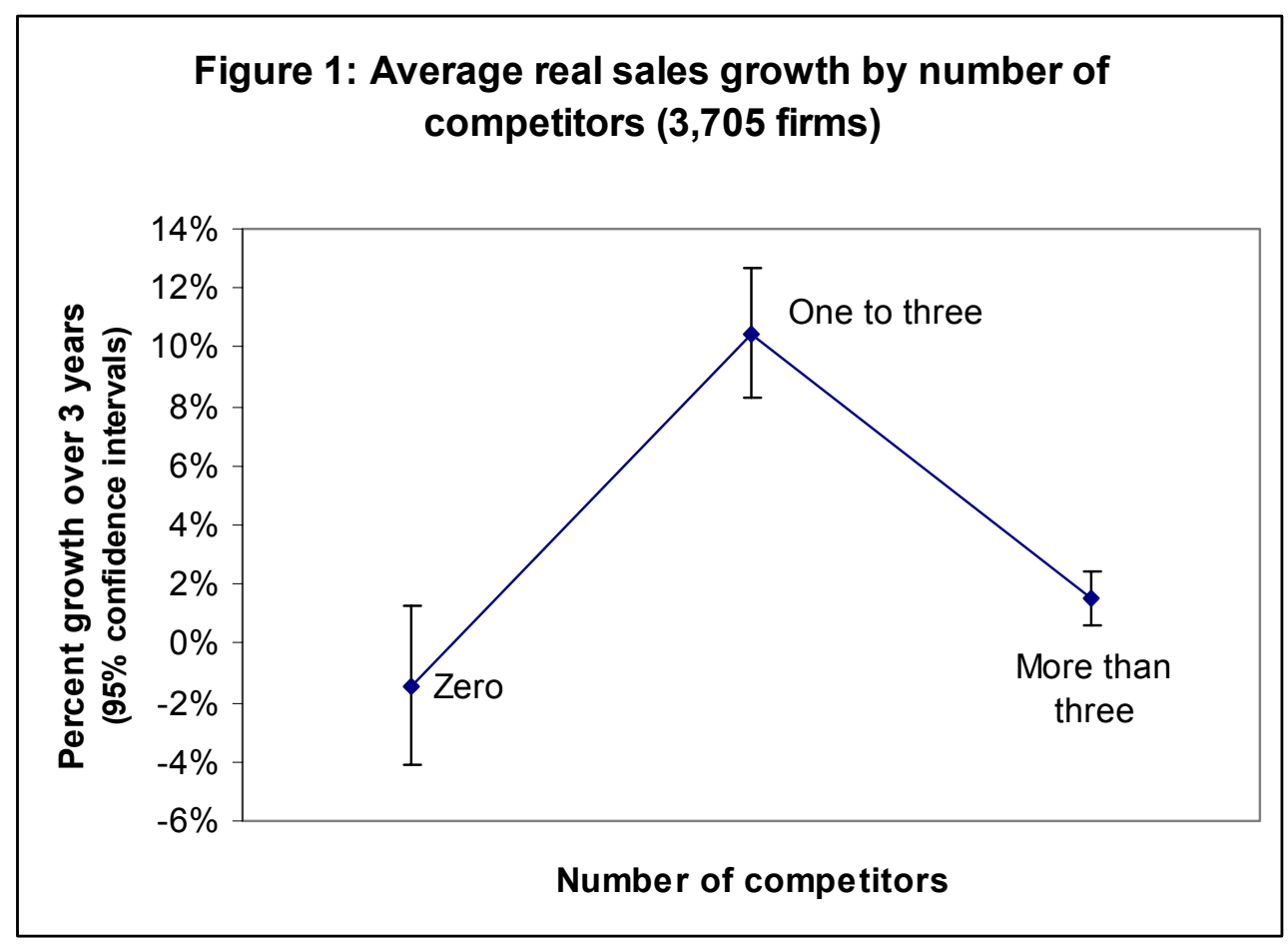

Our evidence comes from a face-to-face survey of competition and innovation in nearly 4,000 firms in 24 transition countries conducted in 1999. This evidence offers a number of advantages over previous work. First of all, countries at the beginning of the transition from central planning to the market economy offer a historically unique opportunity to observe large numbers of firms simultaneously facing opportunities for innovation. In a market economy at any one time, the firms that we observe typically face widely divergent opportunities for innovation: it is therefore difficult to know to what extent 
variations in actual innovative activity are due to variations in responsiveness to opportunity, and to what extent they are due to variations in the opportunities themselves. For instance, firms that innovate relatively little in any one period may be relatively unresponsive to opportunity, or they may have undertaken innovation in earlier periods and already be occupying an optimal market niche. Conversely, firms that innovate more in any one period may be those that are responding rapidly to current opportunities, or those that are responding slowly to past opportunities. Of course, if the distribution of innovation opportunities were completely random, such differences would just add noise to the data without biasing the estimation. But there are many reasons to think that innovations cluster, and that in any period they will be more concentrated among firms of certain categories (of size and market position, for instance) than others. By contrast, the early years of the transition provide as close to a laboratory for responsiveness to innovation as we may ever come. Virtually every firm that emerged from central planning was maladapted to the new environment, and virtually every firm needed to innovate at least modestly in order to survive.

A second important advantage of the data we report here is that the survey is specifically designed to investigate the impact of competition on innovation and growth. It contains a number of questions that elicit from firms a much more intuitive and economically-grounded view of their competitive circumstances than has previously been possibly in surveys on this scale. It also contains detailed questions about the innovative activities undertaken by managers. These provide us with the opportunity of investigating the impact of competition on innovation as the first step and then in the second step, looking at how competitive conditions influence output growth as distinct from their effect on innovation.

The concern raised in many studies of the effects of competition on firm performance in mature market economies is that in the long run, successful performance brings with it an increase in market share and more market power. Reverse causality of this kind will put an upward bias on measures of market power in a performance regression. However, although our data and measures of growth and innovation cannot entirely eliminate such worries, they go a considerable way to mitigating them.

Transition economies were subjected to a comprehensive economy-wide shock to competition. This shock had the effect of introducing competition between existing firms in 
an environment where there was previously none, of removing automatic state financial support thus creating the incentive for managers of existing firms to attend to competitive conditions (in domestic and export markets), of opening the way for the entry of new firms, and of introducing competition from imports. There are therefore two kinds of firms in the sample: 'old' firms that existed under the planned economy and either remain state-owned or are privatized and 'new' firms that had no predecessor in the pre-reform economy.

Broadly speaking, the large, established firms in the sample are likely to operate in markets, the structure of which at the time of the survey is still strongly influenced by the pretransition arrangements in which competitive success was not a determinant of market structure. The new firms making up the bulk of the sample are mainly small and more plausibly characterized as responding to market conditions than establishing them. Furthermore, since all new firms are relatively young (founded between 1990 and 1996), to the extent that there is some endogeneity of market structure it will affect them to a similar degree. As we shall see when we inspect the data, market power is much more characteristic of state-owned firms than of others: such firms had privileged access to resources in the old regime. At the time of the survey, transition economies were distant from an equilibrium in which market structure was the outcome of the playing out of competitive forces.

For these reasons, transition economies observed at the time of this survey may constitute a closer approximation to a large-scale 'natural experiment' in which we can examine the effects of competition on behaviour and performance than we are ever likely to find again, at least on such a scale. Furthermore, by analyzing separately the way competition affects performance for the two sub-samples of new firms and established firms we may obtain a qualitative and quantitative indication of the changing character of market structure, which will assist us in interpreting the results for the sample as a whole.

To summarize, two features of the transition context lessen concern about reverse causality between firm success and measures of competition: on the one hand, aspects of market structure and the competitive pressure faced by firms were inherited from the command economy and on the other, for many firms, their competitive context is the outcome of random events during the liberalisation process early in the transition. 
Of course, one disadvantage of the natural experiment offered by transition is that a change in the degree of competition was only one of many changes to the economic environment. In particular, many countries implemented privatisation programmes, as well as changes in regulations affecting a large number of aspects of the business environment. All these countries have also been going through a profound social transformation that affects everything from the aspirations of entrepreneurs to perceptions of the socially acceptable level of corruption. In order to isolate the influence of competition, we control for a number of general features of firms and their external environment (e.g., their size, whether they existed under central planning or not, economic sector and location). Other elements of the institutional and policy environment will vary across countries and will be captured in the country dummies.

The structure of the paper is as follows. In section 2 we review briefly the theoretical and empirical literature on the link between competition and growth - do we have any reason to expect there to be a link at all? In section 3 we describe our data, and in section 4 we discuss empirical specifications. Sections 5 and 6 present our results and section 7 concludes.

\section{Why should competition matter for innovation and for the growth of firms?}

Whilst there is a clear consensus in theoretical and empirical work that stronger competition improves allocative efficiency in most types of industries, the connection between competition and both innovation and growth is much more contentious. Schumpeter identified the countervailing pressures at work in 1943 and it is more than a half century later that theoretical work has been able to formalize the mechanisms he described and that bestpractice empirical analysis has begun to find ways of separating out the effects in the data.

Schumpeter's vision of the capitalist economy was of a system in which incumbents with market power are constantly being threatened both by existing competitors and by new entrants (Schumpeter 1943, Carlin, Haskel and Seabright, 2001). Innovation is spurred by the potential rents that would come from success in a necessarily risky activity and by the need to innovate to maintain existing rents in the face of competitive threat. He also emphasized that innovation is costly, that financial markets are imperfect and that internal funds are often necessary in order for a firm to innovate. This analysis suggests that on the one hand market power can boost innovation: higher rents enable more innovation to be undertaken (resources) and increase the rewards to such innovation as occurs (incentives), whilst on the 
other hand, more competition can also boost innovation: incumbents who fail to innovate will be pushed out by innovating incumbents or entrants. In his vision of how the competitive process works, these counteracting forces are simultaneously present. The subtlety of Schumpeter's analysis does not therefore lend itself to a simple hypothesis such as 'more competition raises/lowers innovation' that can be taken to the data. His analysis distinguishes between actual rents (resources), perceived rents (post-innovation), actual competition and potential competition.

Considerable progress has been made in recent years in building formal models in both industrial organization and in growth theory that capture several aspects of the Schumpeterian competitive process. A survey of models from both traditions is provided in Aghion and Griffith (2004). Taking incentive effects first, in addition to the classic Schumpeterian effect of greater ex post competition depressing the incentive to innovate (as in Aghion and Howitt 1998), other models have shown how the adverse effects of knowledge spillovers to competitors on the incentive to invest may offset the direct productivityenhancing impact of the spillovers themselves (e.g. Dutta \& Seabright, 2002). The opposite relationship with greater competition inducing productivity growth is captured in some models. For example, the emergence of new competitors threatens the temporary monopoly profits from innovation and the survival of incumbents, which prompts satisficing managers to exert effort and shorten the innovation cycle (Aghion, Dewatripont \& Rey 1997). More recently, the basic Schumpeterian model has been extended by allowing incumbent firms to innovate (Aghion, Harris, Howitt \& Vickers 2001). This produces an inverse-U shaped relationship between competition and innovation. At low levels of competition, the incentive to innovate is sharpened as more competition raises the incremental profits from innovation. When competition becomes intense, further competition may inhibit innovation as the standard Schumpeterian effect offsets the pressure to innovate so as to escape competition.

Empirical support for the role of competition as a spur to performance comes from recent econometric research using a variety of performance measures. For instance, Blundell, Griffith and Van Reenen (1999) use numbers of innovations as a measure and are able to reconcile the fact that large firms are more likely to innovate with the positive role of competition in innovation. They show both that firms with larger market shares have more to gain by innovating in a pre-emptive fashion (potential competitive threat) and that in industries where competition is less intense, rates of innovation are lower. The results are 
consistent with those of a quite different methodology (bench-marking using case studies) in which Baily and Gersbach (1995) find that "head-to-head" competition in the same market results in faster innovation in several manufacturing industries. Nickell (1996) controls for industry level concentration and import concentration and finds that a firm-level measure of competition is correlated with TFP growth. A robust inverse U-relationship between product market competition and the patenting activity of UK firms consistent with the counteracting Schumpeterian mechanisms set out in Aghion, Harris, Howitt \& Vickers (2001) is reported in Aghion, Bloom, Blundell, Griffith \& Howitt (2003).

Evidence that only a few competitors is sufficient to sharpen incentives is provided in an empirical study of entry thresholds. Bresnahan and Reiss (1991) find that most of the competitive impact from entry comes from the first two entrants to challenge a monopolist, with the effect levelling out once market participants number around five.

Nickell motivates his 1996 paper by observing that the most convincing evidence for the role of competition in innovation and growth comes from a 'broad brush' comparison between the lack of dynamism of centrally planned as compared with market economies (Nickell, 1996). Studies are beginning to emerge that examine the role of competition in the transition from central planning to the market economy. Grosfeld and Tressel (2002) apply Nickell's methodology to a panel of Polish firms listed on the stock market. They find that a reduction of 10 percentage points in the firm's market share is associated with faster total factor productivity growth of 1.4 percentage points. Using a measure of competition at industry level, Konings (1998) found in a study of Bulgaria and Estonia that more competitive pressure in the industry enhanced firm TFP growth in Bulgaria but not in Estonia. A recent attempt has been made to use the statistical technique of meta-analysis to synthesize the empirical results of over one hundred studies of transition economies (Djankov and Murrell, 2002). Although there are important questions about the reliability of metaanalysis techniques, especially where there is reason to suspect that empirical biases may be correlated across studies, ${ }^{3}$ their findings are nevertheless illuminating. Djankov and Murrell (2002) pool 23 studies (using mainly level but with some growth rate measures) and report a positive impact of competition on performance (see Table 7 in Djankov and Murrell for the estimated size of the effects). Finally, a study of Georgian firms (Djankov and Kreacic 1998)

\footnotetext{
${ }^{3}$ For a survey of the methodological problems associated with 'narrative' and meta-analysis reviews, see Chalmers and Altman (1995).
} 
that collected information on actions taken by managers found that competition from foreign producers tended to be associated with employment cuts and changes in suppliers (but tended to reduce the likelihood of the disposal of assets, renovations and computerization). By contrast, firms with a larger market share were more likely to engage in computerization, introduce renovations, establish a new marketing department and dispose of assets.

Naturally, all studies of the impact of competition need to control for other factors, and studies vary in the extent and manner in which they do so. One such factor is ownership. Since privately-owned firms also tend to operate in a different competitive environment, failure to control for ownership might lead to significant bias. Pooling 37 studies and placing more weight on studies that controlled for selection bias in the privatization process, Djankov and Murrell (2002) found that privatization improved performance significantly (the majority of studies used levels rather than growth rate measures, see Djankov and Murrell Table 2). For the Commonwealth of Independent States (CIS) countries (former Soviet Union), however, there was no robust significant difference between the performance of state-owned and privatized firms.

Bearing these findings in mind, as well as the fact that in our data it is impossible to take into account the endogeneity of the privatisation decision by correcting for selection bias, we do not distinguish separately between privatised firms and ones that were stateowned at the time of the survey. We can report, however, that this distinction proved insignificant in our preliminary work: any positive bias on the effect of privatization due to selection effects was not strong enough to produce a significant difference in performance between state-owned and privatized firms once competition, size and sector were controlled for. The relevant distinction in the data appears to be between old and new firms rather than between state-owned and private (i.e. privatized plus new) ones. This distinction also raises fewer econometric problems since the difference between old and new firms is given by history.

To summarise, theory provides good reasons to expect that monopolists will be less dynamic and innovative than rivalrous oligopolists, with a small number of exceptions in naturally monopolistic industries. Empirical evidence tends to confirm this view. Both theory and evidence are less clear, however, as to whether competition has a monotonically beneficial effect on performance or whether many competitors are actually less good for 
performance than just a few. Theory and evidence also suggest that any attempt to test for such a relationship needs to control for firm and industry characteristics, as well as for relevant features of the external environment.

It is evident that the theories we have outlined above do not provide sufficiently precise empirical predictions for us to be able to distinguish one theory from another; instead they provide a guide as to certain empirical tendencies for which one can test (such as whether the effect of competition is monotonic). Nevertheless, we can tentatively draw a distinction between theories that appeal to the effect of competition on managerial incentives (on how keenly managers will wish to ensure the efficient use of the firm's resources), and those that appeal to the effect of competition on the resources over which managers enjoy discretionary control. The former type of effect could well be non-monotonic: for firms in which monetary rewards for managers are weak, lack of rivalry may make managers lazy, while too much rivalry may make them resigned to their fate. Equally in profit-maximizing firms, the incentive to escape competition by innovating may be strong at low levels of competition but be offset by the standard Schumpeterian effect when competition is high, again producing an inverted $U$ pattern. However, the effect of managerial resources is more likely to be monotonic, but to depend qualitatively on how well aligned are the incentives of the managers and the shareholders. Managers acting efficiently will tend to do more for the firm the more resources they have to play with, while those acting inefficiently will tend to do worse, the more resources they have to play with. We explore this suggestion further in the regressions we report in section 6 below. Our data is ideal for this purpose since in the new post-reform competitive environment of transition countries, we have both old firms, which can be assumed to be characterized by relatively weak monetary incentives for managers, and new firms, where monetary incentives are strong.

\section{Data and Variables}

Our objective is to make use of a large multi-country cross-sectional firm-level dataset to examine the determinants of innovation and growth at the level of the firm. Although there are serious shortcomings with the data that limit the analysis that can be undertaken, these are balanced by the opportunities afforded by bespoke data-collection on this scale. The key disadvantages stem from the fact that there is no panel structure and that the data is selfreported rather than of an accounting or administrative nature. On the other hand, information 
collected from firms of all sizes across all sectors in a large number of economies following a major shock to the competitive environment is a potentially rich source of evidence to complement the insights from more conventional data-sets.

We discuss the nature of the survey and the data collected and then in turn the issues raised by the measurement of growth, innovation and competition.

\section{The BEEPS enterprise survey}

A major effort at the collection of firm-level data on enterprise performance and the external environment of firms in transition economies was undertaken in 1999 by the EBRD and World Bank. Face-to-face interviews at enterprises in twenty transition countries were conducted in the early summer of 1999. Surveys of five more transition countries were completed later in 1999. The aim was to investigate how enterprise restructuring behaviour and performance were related to competitive pressure, the quality of the business environment, and the relationship between enterprises and the state.

The survey sample was designed to be broadly representative of the population of the firms according to their economic significance, sector, size and geographical location within each country. The sectoral composition of the total sample in each country in terms of agriculture, industry and services was determined by their relative contribution to GDP after allowing certain excluded sectors. Firms that operated in sectors subject to government price regulation and prudential supervision were excluded from the sample. Within each sector, the sample was designed to be as representative as possible of the population of firms subject to various minimum quotas for the total sample in each country. This approach sought to achieve a representative cross-section of firms while ensuring sufficient weight in the tails of the distribution of firms for key control parameters (size, geographical location, exports, and ownership).

The survey was implemented on behalf of the EBRD and World Bank by AC Nielsen through face-to-face interviews with each of the respondents in their local language (see Appendix). They were informed that the EBRD and World Bank had commissioned the survey and that the identity of the survey respondents was to be kept strictly confidential by the survey firm. The interviewers assured respondents that their identity would not be 
disclosed either to the two sponsoring institutions or to the government. In order to collect evidence on the role of competition in growth and restructuring, we designed a block of questions to be included in the BEEPS survey.

The full sample size was 3,954 firms. The survey included approximately 125 firms from each of the 24 countries, with larger samples in Poland and Ukraine (over 200 firms) and in Russia (over 500 firms). We omit from the analysis firms missing any of the most basic indicators (industry, size classification, ownership classification, sales growth and employment growth) leaving us with a sample of 3,837 firms. The econometric analysis in the next section removes all firms with missing values in any variable in use, reducing the sample to between 3,288 and 3,448 firms.

Just over half the firms in the sample were newly-established private firms, $32 \%$ were privatized and 16\% remained in state ownership at the time of the survey. Table 1 provides some basic information on the distribution by size, sector and region of the sample of firms. The sample is dominated by small and medium-sized enterprises; one-half the sampled firms employed fewer than 50 persons, and just over one-fifth employed more than 200. Nearly one half of firms are from the service sector and 12\% are from agriculture. $30 \%$ of firms are from the manufacturing sector. Just under one-third of the sample is from the Central and Eastern European region (including the Baltics) and nearly 10\% of firms are Russian. Most firms were located in either large cities or national capitals $(36 \%)$ or in medium-sized cities $(32 \%)$, with the remaining $32 \%$ in towns and rural areas. 
Table 1. Number of firms by size, sector and region.

(In proportion of firm type, \%)

\begin{tabular}{|l|l|l|l|l|l|l|l|}
\hline & & $\begin{array}{l}\text { Agricul- } \\
\text { ture }\end{array}$ & $\begin{array}{l}\text { Manufact- } \\
\text { uring }\end{array}$ & $\begin{array}{l}\text { Other } \\
\text { industry }\end{array}$ & $\begin{array}{l}\text { Retail \& } \\
\text { wholesale } \\
\text { trade }\end{array}$ & $\begin{array}{l}\text { Other } \\
\text { services }\end{array}$ & Total \\
\hline \multirow{2}{*}{$\begin{array}{l}\text { Full } \\
\text { sample }\end{array}$} & All firms & $441(11.5)$ & $1157(30.2)$ & $380(9.9)$ & $1090(28.4)$ & $769(20.0)$ & $3837(100)$ \\
\cline { 2 - 8 } & Micro & 40 & 179 & 73 & 520 & 234 & $1046(27.3)$ \\
\cline { 2 - 8 } & Small & 49 & 215 & 96 & 310 & 137 & $843(22.0)$ \\
\cline { 2 - 8 } & Medium & 155 & 383 & 142 & 191 & 214 & $1085(28.3)$ \\
\cline { 2 - 8 } & Large & 197 & 380 & 69 & 69 & 148 & $863(22.5)$ \\
\hline CEB & $58(4.9)$ & $319(27.2)$ & $93(7.9)$ & $364(31.0)$ & $341(29.0)$ & $1175(100)$ \\
\hline SEE & $26(3.1)$ & $346(41.7)$ & $72(8.7)$ & $226(27.2)$ & $160(19.3)$ & $830(100)$ \\
\hline Russia & $125(22.8)$ & $139(25.3)$ & $66(12.0)$ & $165(30.1)$ & $54(9.8)$ & $549(100)$ \\
\hline Western CIS & $57(15.3)$ & $120(32.2)$ & $47(12.6)$ & $105(28.2)$ & $44(11.8)$ & $373(100)$ \\
\hline Southern CIS & $72(14.0)$ & $125(24.4)$ & $52(10.1)$ & $173(33.7)$ & $91(17.7)$ & $513(100)$ \\
\hline Central Asia & $103(25.9)$ & $108(27.2)$ & $50(12.6)$ & $57(14.4)$ & $79(19.9)$ & $397(100)$ \\
\hline
\end{tabular}

Note. Micro firms (employment < 10); small firms (employment 10-49); medium firms (50-199), large (>200). "Other industry" comprises mining, construction and electricity; "other services" comprises transport, financial, personal, business and miscellaneous services. $\mathrm{CEB}=\mathrm{Central}$ Europe \& Baltics, $\mathrm{SEE}=$ South-Eastern Europe.

The measurement of performance: growth and innovation

Table 2 presents data on the average performance by firms using the performance measures that we concentrate on in this paper: the growth of real sales, of real sales per worker and the engagement of firms in innovation activities. The growth measures were calculated from self-reported figures for the real growth of sales and of employment over the previous three years. It is important to note that there is no true time-series dimension. We have only self-reported information on the change in real sales as well as on the kinds of restructuring activities carried out by the firms over the preceding three years. We need to keep these limitations in mind when analyzing the results.

In the sample as a whole, $32 \%$ of firms reported a contraction in sales (in real terms) over the previous three years; just under one-quarter reported flat sales and just over $44 \%$ reported growing sales. The Central and Eastern European region including the Baltic States (CEB) and the South East European region (SEE) were the only regions in which more than one half of firms reported growing sales. In line with the macroeconomic performance across different regions, the proportion of firms with shrinking sales in a region ranged from just over one-fifth in CEB to one-third in Russia and $40 \%$ in the Western and Southern CIS.

For old firms (state-owned and privatized), average growth of sales was negative; it was positive for new firms. The opposite was true of productivity growth: average growth of sales per worker was negative in new firms and positive in old ones. For both privatized and 
new private firms, average growth increased with the size of the firm. This was not the case for state firms. In old firms, where between 55 and $60 \%$ of firms had declining sales, the more rapid shedding of labour than reduction of output lies behind the positive productivity growth recorded. In new firms, average productivity growth was negative but there is a clear size effect: as we move to higher size classes, productivity growth becomes less negative. In the largest size class, positive productivity growth was recorded for new firms. A possible explanation for this size effect is the endogeneity of size. Larger firms may be larger at the time of survey because they grew faster (or shrank less rapidly); we return to this issue in the next section when we discuss our econometric estimations.

In addition to measures of performance based on sales growth, we sought to uncover the steps undertaken by firms to improve their performance through innovation. ${ }^{4}$ To capture the extent of their innovative activities, firms were asked questions about whether they had developed a new product line or upgraded an existing one, whether they had opened a new plant, and whether they had obtained ISO9000 quality accreditation in the previous three years. Table 2 shows that $40 \%$ of all firms upgraded at least one product, $30 \%$ introduced a new product, $20 \%$ opened a new plant and 15\% obtained ISO9000 quality accreditation. Engagement in these activities was common across all firm types, including state-owned firms.

The innovation variable used in our estimations is constructed using the method of principal components analysis from responses to the questions described above. ${ }^{5}$ For our innovation measure $r$ we used responses to the four restructuring questions. The first of the four components explains $44 \%$ of the total variation, more than double that of the second component. The introduction of a new product or upgrading an existing one are given the largest weights in the construction of the index. The index is normalized so that the minimum value is zero and the maximum value is the number of possible restructuring measures. This is done to facilitate interpretation of the regression results - a unit increase in the index corresponds, roughly speaking, to the introduction of another restructuring measure.

\footnotetext{
${ }^{4}$ Patterns of cost-oriented or defensive restructuring are explored in Carlin, Fries, Seabright and Schaffer (2001).

${ }^{5}$ The use of these summary measures is more conservative than the alternative of including all the individual components as explanatory variables in the various regressions. With so many regressors, a likely outcome of this alternative procedure is a finding that some regressors are significant and with the expected sign, some are insignificant, and some are significant but with the opposite of the expected sign, making it difficult to reach an overall interpretation of the results.
} 
Table 2. Real sales and productivity growth and restructuring/innovation by ownership of firm

Mean of $\log 3$-year real sales and productivity growth

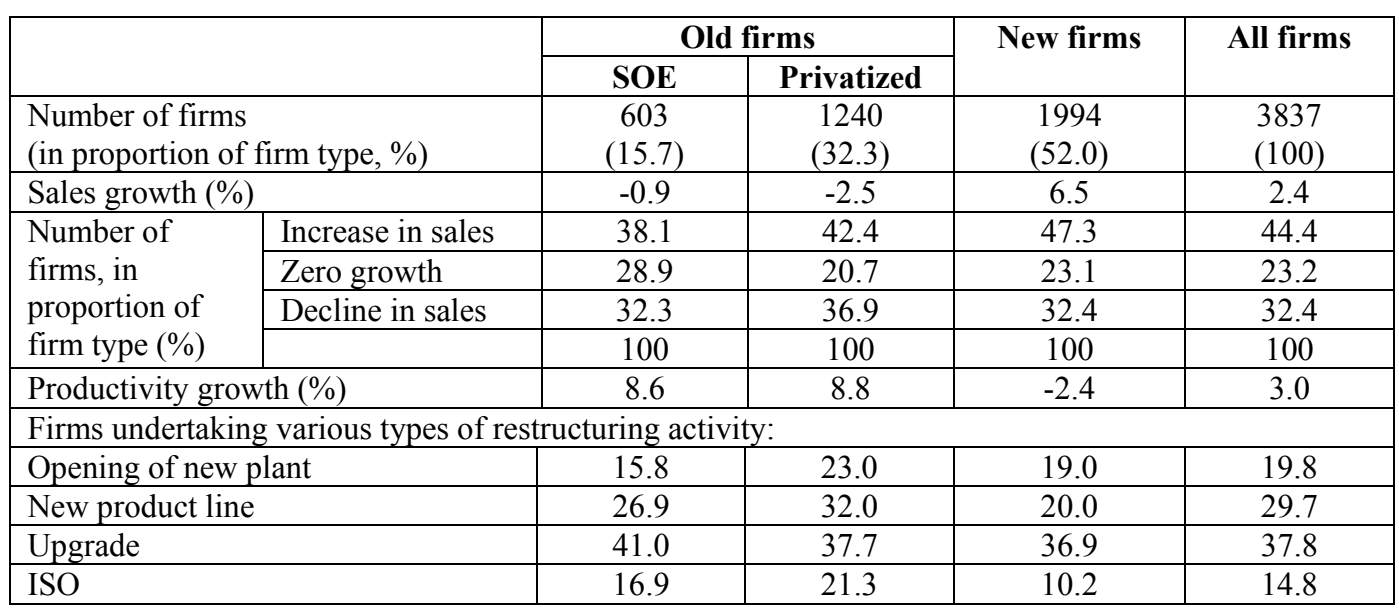

Note: The question asked was, "By what percentage have your sales changed in real terms over the last three years?" "Productivity" growth is calculated from the change in sales and in employment reported over the last three years. All restructuring indicators refer to changes in the previous three years. "New product line" refers to the successful development of a major new product line. "Upgrade" refers to the upgrading of an existing product line. "ISO" refers to the receipt of an ISO9000 accreditation.

\section{The measurement of competition}

One common and intuitive starting point for measuring competition is the extent to which production is concentrated in the hands of a few firms. The crudest measure of this concentration is simply the number of firms that are operating in the same or a recognisably similar market. To be useful this measure depends on there being some practical method of defining the relevant market (see Neven et.al., 1993, chapter 2), which essentially means finding goods and services that are reasonably close substitutes for each other while being distant substitutes for all other goods or services. But while this may be a useful first indicator, it may be seriously misleading when there are important differences in size, strength and productivity between firms. For example, the exit of one large firm and entry of many small ones may reduce conventionally measured concentration but lower the vigour of the rivalry faced by the remaining large firms. This problem has been observed in transition countries where the exit of one or two large enterprises from an industry along with the simultaneous entry of many new small firms has resulted in a reduction in effective competition (see Kattuman and Domanski, 1998 on Poland). One way of dealing with this is by calculating measures of market power at the firm rather than the market level, in particular by looking directly at the market share of each individual firm or by asking managers to 
provide a judgement as to the number of competitors they believe the firm faces in its main market.

A second way of measuring competition is to look at some of the consequences of market structure rather than market structure itself, and specifically at the freedom firms have to choose prices (and other business strategies) independently of any concern about losing business to other firms. A natural way to do this is to estimate the so-called residual elasticity of demand for the firm's own products, namely the extent to which a price rise by the firm would lead customers to substitute away, either to rival firms or away from the product altogether. When sophisticated data are available, this elasticity can sometimes be estimated econometrically (see Hausman et.al., 1992, for an application to the case of beer), and it is particularly useful to do so when products are differentiated so that the notion of a single product market may make little sense.

A third and altogether different approach to measuring competition is to look directly at the behaviour of firms and to infer from this the extent of the rivalry they believe themselves to face. In particular, the price-cost margin charged by a profit-maximising firm facing constant marginal costs (given by the technology and not capable of being influenced by the firm itself) will be inversely proportional to the own-price elasticity of demand for its products. If price-cost margins can be reliably measured, therefore, they may themselves be an inverse indicator of the vigour of competition in the market.

The survey instrument was expressly designed to discover the extent to which firms believed themselves to be facing significant competitive challenge using each of these kinds of measures.

- As a measure of market structure we use the number of competitors reported by the respondent in the market for its main product, dividing firms into those reporting respectively no competitors, between one and three competitors and more than three competitors. Note that although this looks like a simple market concentration measure, it measures concentration in what the firm believes to be its main market, rather than the administrative category of products the firm is placed in by the national statistical agency. In particular, in a survey with coverage of the entire economy, this is likely to provide an economically meaningful measure of 
competition whether the firm is a pizza parlour or a components supplier for a multinational company.

- As a measure of firms' freedom to raise prices we use their response to a question asking them what would be the consequence of a $10 \%$ rise in the real price of their product relative to that of their competitors, scoring from one (for firms reporting that most customers would switch to rival suppliers) to four (for firms reporting that most customers would continue to buy in similar quantities as previously).

- As a measure of firms' behaviour we use their (self-reported) price-cost margin.

We can ask two questions about these different ways of measuring competition. First, are they empirically consistent one another, in the sense that they identify the same firms as possessing market power? And secondly, are they just alternative empirical proxies for the same phenomenon, or do they measure distinct aspects of market power? To answer the first question, we report in Table 3 mean values of the second and third measure for firms categorised by the first measure, and sub-categorised by ownership status (state firm, privatised firm and other) in order to control for different degrees of commitment to profitmaximising behaviour. The answers clearly indicate that in markets with no competitors firms report lower own-price elasticities of demand and higher price-cost margins than in markets with 1-3 competitors. The exception is for state firms, where the price-cost margin is lower for firms facing 1-3 competitors than for either of the other categories (as one might expect given their weaker incentives for profit-maximisation). It appears that the responses to these three questions complement one another, which is reassuring in terms of the economic content of the data. The questions asked about the number of competitors appear to have focused the attention of managers on an economically relevant concept of the 'market' in which they are competing. Nevertheless, the somewhat counter-intuitive behaviour of the price-cost margin for state firms leads us to prefer not to use this as an indicator of market power in the regressions below. 
Table 3. Competition and concentration

Market power (10\% test, answer from 1 - all customers switch - to 4 - customers continue to buy as before) and price-cost margin, by ownership and number of competitors

\begin{tabular}{|c|c|c|c|c|}
\hline & \multicolumn{4}{|c|}{ Number of competitors } \\
\hline & None & 1 to 3 & $>3$ & Total \\
\hline $\begin{array}{l}\text { State-owned Enterprises } \\
\text { Number of firms } \\
\text { (in proportion of firm type, \%) } \\
\% \text { price-cost margin } \\
10 \% \text { test (answer from } 1 \text { to } 4 \text { ) }\end{array}$ & $\begin{array}{c}154 \\
(25.5) \\
15.3 \\
3.08 \\
\end{array}$ & $\begin{array}{c}108 \\
(17.9) \\
12.1 \\
2.48 \\
\end{array}$ & $\begin{array}{c}341 \\
(56.6) \\
16.0 \\
2.25 \\
\end{array}$ & $\begin{array}{l}603 \\
15.1 \\
2.50 \\
\end{array}$ \\
\hline $\begin{array}{l}\text { Privatized firms } \\
\text { Number of firms } \\
\text { (in proportion of firm type, \%) } \\
\% \text { price-cost margin } \\
10 \% \text { test (answer from } 1 \text { to } 4 \text { ) }\end{array}$ & $\begin{array}{c}96 \\
(7.7) \\
18.3 \\
2.65 \\
\end{array}$ & $\begin{array}{c}160 \\
(12.9) \\
15.4 \\
2.38 \\
\end{array}$ & $\begin{array}{r}984 \\
(79.4) \\
15.4 \\
2.13 \\
\end{array}$ & $\begin{array}{l}1240 \\
15.6 \\
2.20 \\
\end{array}$ \\
\hline $\begin{array}{l}\text { New firms } \\
\text { Number of firms } \\
\text { (in proportion of firm type, \%) } \\
\% \text { price-cost margin } \\
10 \% \text { test (answer from } 1 \text { to } 4 \text { ) }\end{array}$ & $\begin{array}{c}97 \\
(4.9) \\
22.7 \\
2.42 \\
\end{array}$ & $\begin{array}{c}236 \\
(11.8) \\
20.5 \\
2.39 \\
\end{array}$ & $\begin{array}{c}1661 \\
(83.3) \\
17.4 \\
2.25 \\
\end{array}$ & $\begin{array}{l}1994 \\
18.0 \\
2.50 \\
\end{array}$ \\
\hline $\begin{array}{l}\text { All firms } \\
\text { Number of firms } \\
\text { (in proportion of all firms, \%) } \\
\% \text { price-cost margin } \\
10 \% \text { test (answer from } 1 \text { to } 4 \text { ) }\end{array}$ & $\begin{array}{l}347 \\
(9.0) \\
18.3 \\
2.78\end{array}$ & $\begin{array}{c}504 \\
(13.1) \\
17.0 \\
2.40\end{array}$ & $\begin{array}{c}2986 \\
(77.8) \\
16.6 \\
2.07\end{array}$ & $\begin{array}{l}3837 \\
16.7 \\
2.18\end{array}$ \\
\hline
\end{tabular}

To answer the second question (about whether these measure distinct aspects of market power) we shall investigate in detail the ways in which they interact with our measures of performance; we do so in section 6 below. However, we can make some general empirical predictions at this stage. First, if these measures were just imperfect proxies for the same basic phenomenon ('market power') we would expect that each of them would have a stronger impact when entered singly in a performance regression than when entered in the presence of the other (that is, entering a second measure would reduce the explanatory power of the first). In fact, as we shall see, the explanatory power of the measures appears to be more or less unchanged whether entered singly or together, which suggests that they may be identifying distinct aspects of market power.

So what might these distinct aspects of market power be? We distinguished above between theories that appeal to the effect of competition on managerial incentives, and those that appeal to the effect of competition on the resources over which managers enjoy discretionary control. It seems reasonable to suggest that the perceived number of competitors is likely to capture the motivation of managers, while the freedom to raise prices 
will capture their control over resources (the rents available to them). This prompts a second empirical prediction: if motivation is strongest when there are 1-3 competitors and weakest when there are none, then more resources should be associated with better performance when there are 1-3 competitors and not associated (or negatively associated) when there are none.

Finally, the survey also sought to investigate the impact of perceived competitive pressure on decisions by managers to undertake restructuring measures (rated in each case on a scale of $1=$ not important to $4=$ very important). The questions about pressure to innovate are important since they enable us to explore more closely how performance improvements come about. A smaller proportion of state firms as compared with other firms reported pressure from domestic competitors as playing a significant role in their decision to enter new markets or introduce new products. Amongst private firms, one in five reported pressures from foreign competitors as significant in stimulating the introduction of new products. New entrants reported less pressure from foreign competition, which may reflect their small average size.

\section{Econometric estimation and modelling strategy}

Our model consists of two structural equations, one for innovation and the second for sales growth, in which we include innovation and the growth of employment, along with other regressors. The second equation may be interpreted as one version of an augmented total factor productivity growth equation. We do not have a measure of the growth of the capital stock but our innovation/restructuring measure includes information on the opening of new plants.

The determinants of innovation are the following:

- Product market competition.

- Market growth.

- Access to resources.

- Managerial incentives.

- Size of firm.

- Controls for industry (innovation opportunities vary by sector), location (to account for agglomeration effects) and country. 
The determinants of sales growth are the following:

- Growth of employment

- Innovation

- Product market competition.

- Access to resources.

- Managerial incentives.

- Controls for industry, location and country.

Before specifying the estimating equations, issues of identification must be addressed in conjunction with data availability. There is a set of variables that theoretical considerations suggest should be in the innovation/restructuring equation but not in the growth equation and vice versa. Variables that on a priori grounds should be excluded from the growth equation are the so-called pressure variables that reflect the view of managers as to the importance of different sources of pressure for their decision to undertake restructuring. Sources of competitive pressure were 'domestic' or 'foreign' competitors. In addition, managers were asked about the role of pressure from customers, which we use as a proxy for the growth of the market. This allows us to exclude sales growth from the innovation equation. The 'pressure' variables are instruments for innovation in the growth equation, the validity of which can be tested. The size of firm is a standard determinant of innovation (reflecting, for example, economies of scale in $\mathrm{R} \& \mathrm{D}$ and marketing) but it is less clear that it has a place in a TFP growth equation. We test whether size is a valid instrument in the growth equation.

Conversely, on a priori grounds, employment growth should be in the growth equation but not in the innovation equation. Since inputs and output may be chosen simultaneously, the possible endogeneity of employment growth in the growth equation must be addressed. Suitable instruments are difficult to find in the survey data so we take two alternative strategies to deal with this. The first is to experiment with an instrument for employment constructed by interacting the country dummies with an exogenous determinant of performance at the level of firm (we use one of the competition measures). The logic of the choice of the country-competition interaction variable is that there is country variation in policies to downsize firms (by adjusting employment). ${ }^{6}$ We refer to these as country-

\footnotetext{
${ }^{6}$ The approach is analogous to the approach adopted in Angrist and Krueger's (1991) study of the returns to education. They estimated earnings equations for a sample of American males in which years of education was an endogenous regressor and dummies for year and state of birth were exogenous regressors. Angrist and
} 
competition interaction effects. Unfortunately diagnostic tests reveal these instruments to be rather weak, so an alternative strategy we use is to impose a range of coefficients on employment growth (from 0.25 to 1 ) and examine the sensitivity of the other coefficients to this variation. Using a coefficient of one is equivalent to estimating a labour productivity growth equation.

As discussed above we interpret the $10 \%$ price test variable as capturing the extent to which managers have discretionary control over resources, and the number of competitors variable, as well as the distinction between old and new firms, as capturing managerial incentives. We report separate estimations for new and old firms as well as pooled estimations

We therefore estimate equation (1) for innovation

$$
\begin{aligned}
r= & \mathrm{a}_{0}+\mathrm{a}_{1} \operatorname{comp}+\mathrm{a}_{2} \text { mpower }+\mathrm{a}_{3} \text { pressure } D+\mathrm{a}_{4} \text { pressureF }+\mathrm{a}_{5} \text { pressureC } \\
& +\mathrm{a}_{6} \text { new }+\mathrm{a}_{7} \text { size }+\mathbf{X a}_{8}+u_{1}
\end{aligned}
$$

and equation (2) for growth

$$
y=\mathrm{b}_{0}+\mathrm{b}_{1} \text { comp }+\mathrm{b}_{2} \text { mpower }+\mathrm{b}_{3} l+\mathrm{b}_{4} r+\mathrm{b}_{5} \text { new }+\mathbf{X b}_{6}+u_{2}
$$

where comp measures the number of competitors, mpower, market power (the $10 \%$ price test), pressureD and pressureF measure the pressure on firms to innovate from respectively domestic and foreign competitors, pressure $C$ measures pressure from customers, new is a dummy denoting the difference between new and old firms and size measure the employment in the firm. The controls for sector and location are denoted by the vector $\mathbf{X}$. In the growth equation, $y$ is the growth of output and $l$ is employment growth. Country fixed effects are included in all regressions.

For the a priori reasons discussed earlier, we take the measures of competition as exogenous to the performance outcomes; the distinction between new and old firms is also exogenous and we assume that sector and location are exogenous. However, by splitting the

Krueger created instruments for years of education by interacting quarter-of-birth with state-of-birth and 
sample between old and new firms, we explore further the possibility that for new firms there may be reverse causality from a recent decision to innovate to its perception of the number of its near competitors.

We are able to deal with the endogeneity of size in a straightforward way. As noted earlier, there may be a spurious correlation between performance as measured over the preceding three years and size as measured at the time of survey, because ceteris paribus firms that grew during the period will tend to be larger at the end of the period. We therefore use average employment during the period as our size measure calculated from observed endperiod employment ${ }^{7}$ and employment growth during the period (both in $\operatorname{logs}$ ). ${ }^{8}$

\section{Estimation methods and diagnostic tests}

For the instrumental variables estimations we employ several diagnostic tests. Our benchmark regression is a two-step efficient GMM chosen because it is efficient in the presence of arbitrary heteroskedasticity, which tests suggest is present. ${ }^{9}$ When there is only one endogenous regressor, we report an F-test of the excluded instruments in the first-stage regression.

We also present a test of overidentifying restrictions, namely the Hansen J statistic. This is a test of the joint hypothesis that the instruments are valid (i.e., uncorrelated with the error term) and that none of the instruments should have been included in the set of regressors and were not. All estimations were done using the Stata statistical package. ${ }^{10}$

\footnotetext{
quarter-of-birth with year-of-birth.

${ }^{7}$ Firms report employment by choosing 1 of 6 size categories; our end-period "log employment" is the log of the midpoint of the reported category.

${ }^{8}$ We note that when the sales growth equation is re-estimated using end-period size, it is positive and highly significant. In the results reported below using average-period size, it is statistically insignificant.

${ }_{9}^{9}$ We also estimated the modification of limited-information maximum likelihood (LIML) proposed by Fuller (1977); we set the Fuller parameter $\alpha=1$, giving us the mean-unbiased version of his estimator. The main motivation for the use of LIML is that recent research suggests it performs relatively well when instruments are weak, which is the case when we treat employment as endogenous. We do not report these results since they were qualitatively identical to the GMM results.

${ }^{10}$ For further details of the estimation routines used, see Baum, Stillman and Schaffer (2003).
} 


\section{Results}

Before estimating the structural equations, we complete the data description by estimating a reduced form equation for sales growth with only the exogenous variables present (as shown in equation (3)). The results constitute our initial check of the bivariate correlation of growth with intense rivalry in the product market illustrated in Fig. 1.

$$
\begin{aligned}
y= & \beta_{0}+\beta_{1} \text { comp }+\beta_{2} \text { mpower }+\beta_{3} \text { pressure } D+\beta_{4} \text { pressure } F+\beta_{5} \text { pressure } C \\
& +\beta_{6} \text { new }+\beta_{7} \text { size }+\mathbf{X} \beta_{8}+u_{3}
\end{aligned}
$$

We also estimate two "semi-reduced" forms which include employment growth, one instrumented and one with an imposed coefficient of unity; however, both estimations include the exogenous determinants of innovation but exclude innovation itself. The equation with an imposed employment growth coefficient of unity is in effect estimating the determinants of labour productivity - and so, given the high estimated labour elasticity of over 0.9 , is the instrumented estimation; our interpretation below uses this terminology.

\section{Reduced and semi-reduced form estimation}

The results of reduced and semi-reduced form estimations of the sales growth indicator on the exogenous variables are shown in Table 4. When interpreting the results, it is important to recall that the average growth of sales and of productivity of firms was close to zero and only just over $40 \%$ of firms reported positive sales growth over the preceding three years. The findings are striking. 
Table 4. Reduced form growth regressions

\begin{tabular}{|c|c|c|c|c|c|c|}
\hline & \multicolumn{2}{|c|}{ (1) } & \multicolumn{2}{|c|}{$(2)$} & \multicolumn{2}{|c|}{ (3) } \\
\hline Dependent variable & \multicolumn{2}{|c|}{$\begin{array}{l}\text { Real sales } \\
\text { growth }\end{array}$} & \multicolumn{2}{|c|}{$\begin{array}{l}\text { Real sales } \\
\text { growth }\end{array}$} & \multicolumn{2}{|c|}{$\begin{array}{l}\text { Real sales } \\
\text { growth }\end{array}$} \\
\hline Estimation method & \multicolumn{2}{|c|}{ OLS } & \multicolumn{2}{|c|}{ GMM } & \multicolumn{2}{|c|}{ OLS } \\
\hline Employment growth & \multicolumn{2}{|c|}{ NO } & \multicolumn{2}{|c|}{$\begin{array}{c}0.923 * * \\
(0.157)\end{array}$} & \multicolumn{2}{|c|}{$\begin{array}{l}\text { Coeff of } 1 \\
\text { imposed }\end{array}$} \\
\hline $\begin{array}{l}\text { Number of competitors } \\
1-3 \text { competitors } \\
>3 \text { competitors }\end{array}$ & \multicolumn{2}{|c|}{$\begin{array}{c}0.099 * * \\
(0.034) \\
0.032 \\
(0.027)\end{array}$} & \multicolumn{2}{|c|}{$\begin{array}{c}0.101 * * \\
(0.032) \\
0.044^{+} \\
(0.027) \\
\end{array}$} & \multicolumn{2}{|c|}{$\begin{array}{c}0.108 * * \\
(0.034) \\
0.052 \\
(0.029) \\
\end{array}$} \\
\hline Tests of number of competitors & vs. 0 & vs. $>3$ & VS. 0 & vs. $>3$ & VS. 0 & vs. $>3$ \\
\hline 1-3 vs. zero $1-3$ vs. $>3$ & $* *$ & $* *$ & $* *$ & * & $* *$ & $*$ \\
\hline $\begin{array}{l}\text { Market power (10\% test) } \\
\text { Sales would fall a lot } \\
\text { Sales would fall slightly } \\
\text { No change in sales }\end{array}$ & $\begin{array}{l}0 . \\
(0 . \\
0.1 \\
(0 . \\
0.1 \\
(0 .\end{array}$ & $\begin{array}{l}38^{+} \\
22) \\
6^{* *} \\
22) \\
5^{* *} \\
26)\end{array}$ & & $\begin{array}{l}\text { 17 } \\
\text { 19) } \\
3 * * \\
19) \\
1 * \\
\text { 26) }\end{array}$ & $\begin{array}{l}0 \\
(0 \\
0.0 \\
(0 . \\
0 . \\
(0 .\end{array}$ & $\begin{array}{l}\text { 19 } \\
20) \\
20 * \\
3 * \\
24)\end{array}$ \\
\hline Pressure from foreign competitors & \multicolumn{2}{|c|}{$\begin{array}{c}0.023 * * \\
(0.008)\end{array}$} & \multicolumn{2}{|c|}{$\begin{array}{c}0.009 \\
(0.007)\end{array}$} & \multicolumn{2}{|c|}{$\begin{array}{c}0.009 \\
(0.007)\end{array}$} \\
\hline Pressure from customers & \multicolumn{2}{|c|}{$\begin{array}{c}0.017^{+} \\
(0.009)\end{array}$} & \multicolumn{2}{|c|}{$\begin{array}{c}0.006 \\
(0.009)\end{array}$} & \multicolumn{2}{|c|}{$\begin{array}{c}0.006 \\
(0.009)\end{array}$} \\
\hline New firm & \multicolumn{2}{|c|}{$\begin{array}{c}0.179 * * \\
(0.021)\end{array}$} & \multicolumn{2}{|c|}{$\begin{array}{l}-0.046 \\
(0.041)\end{array}$} & \multicolumn{2}{|c|}{$\begin{array}{c}-0.062 * * \\
(0.019)\end{array}$} \\
\hline Services & \multicolumn{2}{|c|}{$\begin{array}{c}0.023 \\
(0.019) \\
\end{array}$} & \multicolumn{2}{|c|}{$\begin{array}{c}-0.023 \\
(0.018)\end{array}$} & \multicolumn{2}{|c|}{$\begin{array}{c}-0.027 \\
(0.017) \\
\end{array}$} \\
\hline Agriculture & \multicolumn{2}{|c|}{$\begin{array}{l}(0.030) \\
(0.028) \\
\end{array}$} & \multicolumn{2}{|c|}{$\begin{array}{c}0.013 \\
(0.025)\end{array}$} & & \\
\hline Big city & $\begin{array}{l}0.0 \\
(0 .\end{array}$ & $\begin{array}{l}\text { 5** } \\
19)\end{array}$ & & & & \\
\hline Size (log employment) & $\begin{array}{l}0.0 \\
(0 .\end{array}$ & $\begin{array}{l}8 * * \\
07)\end{array}$ & & 8** & $\begin{array}{l}0.0 \\
(0 .\end{array}$ & \\
\hline Number of observations & & & & & & \\
\hline
\end{tabular}

Notes:

${ }^{+}=$sig. at $10 \%, *=$ sig. at $5 \% ; * *=$ sig. at $1 \%$; heteroskedastic-robust standard errors in () .

The nature of competition in the product market has important effects on the performance of firms in all of these specifications. There are indications of a non-monotonic ('inverse-U') relationship with performance. Sales and productivity growth were higher in firms facing between one and three competitors in the market for their main product than in firms that either faced no competition at all or that faced more than three competitors. The positive effect of an intermediate degree of product market competition is economically as well as statistically significant. Firms facing between one and three competitors reported growth in sales and productivity about $10 \%$ higher than other firms. Firms reporting more than three competitors have a little over $4 \%$ higher growth than monopolists, although this difference is not statistically significant. However, the difference between the growth of firms 
facing one to three competitors and those facing more than three is significant at $5 \%$ in all specifications, indicating that the inverse- $U$ relation is statistically significant in all the reduced-form estimations. As we shall see, it is not always statistically significant in the structural equations capturing the separate component effects, but such an inverse- $U$ is certainly a robust descriptive property of the total impact of product market competition.

The second indication that competition effects are important comes from the positive sign on the variable for firms reporting that sales would fall only slightly or not at all in response to a $10 \%$ price rise. These firms saw productivity growth between $5 \%$ and $13.5 \%$ higher than others depending on the specification.

Thirdly, although the competitive pressure variables are insignificant in the reduced forms for productivity growth, foreign competitors and more weakly, customers boost sales growth. We shall see that they are both important in the innovation equation, to which we now turn.

Controlling for other factors, new firms have significantly higher sales growth than old firms, but lower productivity growth. The weaker productivity growth of new entrants is likely to indicate that such firms were attracting labour faster than their sales were growing. We investigate this further below. Size is positive in both equations, the control variables are not significant and country fixed effects are highly significant. We now explore in more detail the channels by which competition effects appear to be working by turning to the structural equations.

\section{Innovation}

The results for the innovation equation are shown in Table 5. Column (2) is identical to column (1) except that a single indicator has been used for each of the pressure variables. This does not affect the results. We note that although pressure from domestic competitors was included in the initial estimation of this equation, it proved insignificant; we also tested whether it was a valid instrument for innovation in the growth equation but it failed the instrument validity test. It is therefore dropped from the equation. 
Columns (3) and (4) report estimates separately for the sub-samples of old firms and new firms. Although many of the coefficients are remarkably similar for the two samples, the effect of the number of competitors is strikingly different. Old firms display the inverted-U form (the coefficient on 1-3 competitors being significant at 6\%), but new firms show a monotonically decreasing impact of the number of competitors on innovation.

We draw the following conclusions from the results for the innovation equation shown in Table 4:

- The number of competitors is a (weakly) significant positive determinant of the decision to innovate only for old firms (and although there is a hint of an inverse- $\mathrm{U}$, it is not significant at conventional levels). This is consistent with the impact of competitive pressure in raising the incentives of managers of old firms to exert more effort and innovate. For new firms, the number of competitors is negatively related to innovation. This may be due, as we suggested above, to the more likely endogeneity of market structure for new firms - those that have successfully innovated view themselves as having fewer competitors as a result.

- The ability to raise prices as measured by the $10 \%$ test is an important positive determinant of innovation, but so is pressure from foreign competitors. As noted above, pressure from domestic competitors was insignificant. One interpretation of this is that domestic and foreign competition are only imperfect substitutes.

- The positive role of market power in innovation - controlling for both the number of competitors and for the pressure from competitors in the decision to innovate - is suggestive that firms face resource constraints. Rents are needed to finance innovation.

- Pressure from customers is a significant determinant of innovation, which we interpret as capturing the importance of market growth for innovation.

- New firms are more likely to engage in innovation, which supports the hypothesis that managerial incentives play a role.

- Larger firms and those in big cities are much more likely to have engaged in innovation, which is in line with other empirical evidence and suggests that economies of scale in innovation and agglomeration effects are at work in the transition economies.

- Predictable industry effects are confirmed: firms in the service and agricultural sectors are much less likely to have engaged in new product restructuring. 
Table 5. Determinants of innovation

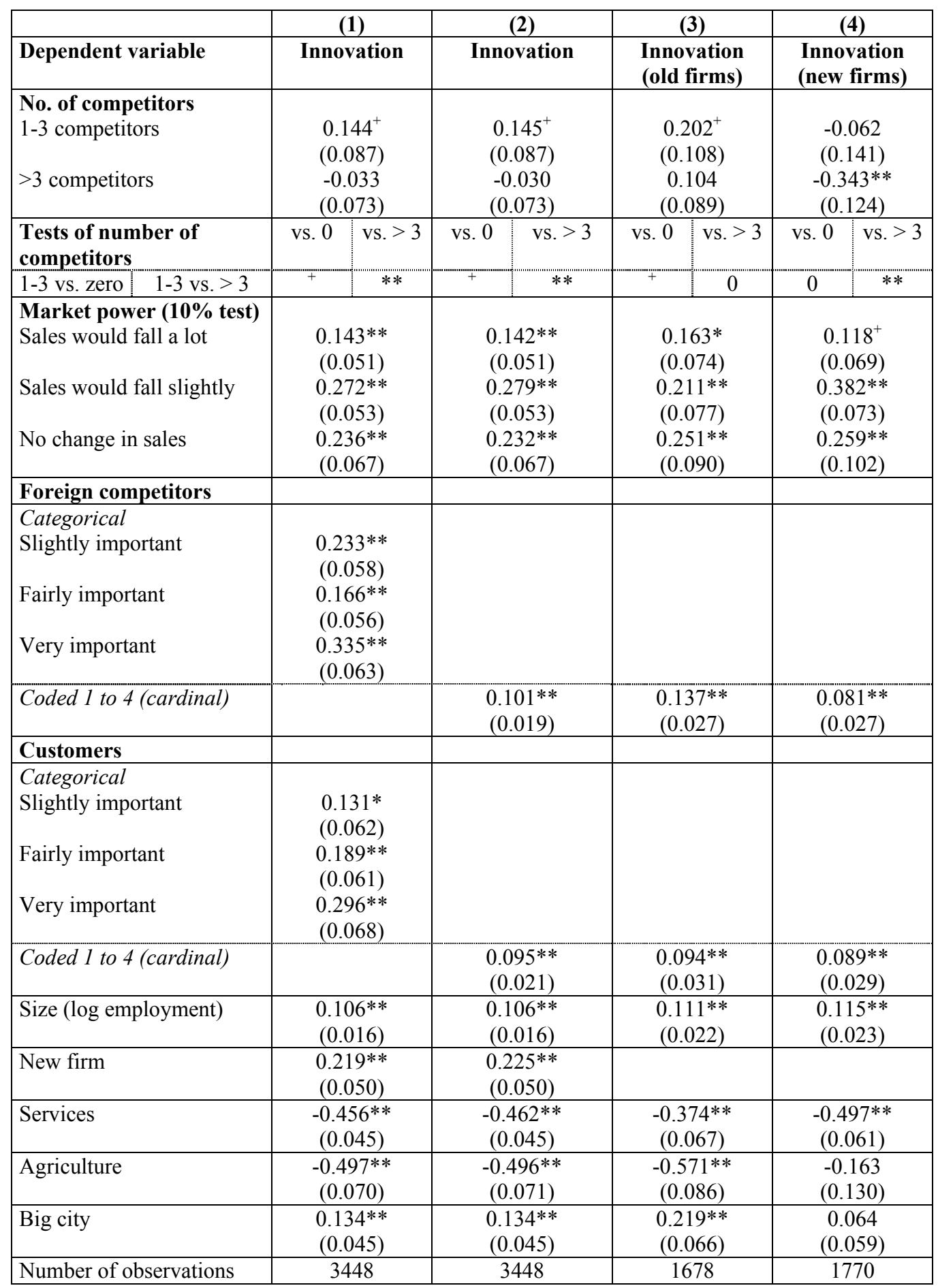

Notes:

$={ }^{+}$sig. at $10 \%, *=$ sig. at $5 \% ; * *=$ sig. at $1 \%$; heteroskedastic-robust standard errors in () .

Test of (1) vs. (2): $\chi^{2}(4)=8.35$, p-value $=0.08$. 
Growth

We look now at the determinants of growth using the estimates of the structural equation (2). Employment growth and innovation are highly significant determinants in the growth equation, which suggests that the equation be interpreted as a form of augmented TFP growth equation. Table 6 shows the results of estimations in which we instrument for innovation. Diagnostic tests on regressions in which both employment and innovation were treated as endogenous revealed a problem of weak instruments, which is not present when only innovation is instrumented. Since we are not directly interested in the size of the coefficient on employment growth, we therefore treat employment growth as exogenous and examine in Table 7 below the sensitivity of the resulting parameter estimates to variations in imposed employment growth coefficients as discussed above.

Column (1) of Table 6 presents the OLS estimates of the growth equation. Columns (2) and (3) present the instrumental variables estimates. The excluded instruments are the 'pressure to innovate' variables and size. The really important feature to emerge from this table is that, for new firms, having between one and three competitors contributes positively and significantly to productivity growth in a direct way, even when the role of innovation is taken into account. Conditional on innovation (which as we have indicated may have an influence on its own on market structure), the presence of rivalry seems to matter for these firms. For old firms by contrast, rivalry matters through its impact on innovation. Market power as measured by the own-price elasticity of demand appears to work partly indirectly, via promoting innovation and partly directly as indicated by its continued significance in the growth regressions. ${ }^{11}$

The only other variable that is consistently significant is the dummy for agriculture. Agriculture attracts a significant negative coefficient in the innovation equation. In the growth regression, it is positive, which indicates that residual productivity growth in firms in agriculture is high relative to firms in other sectors. The other control variables are important for innovation - and therefore indirectly for growth - but play no role in explaining residual productivity growth.

\footnotetext{
${ }^{11}$ Concern about the bias on TFP level estimates in the context of imperfect competition in the product market (Hall 1988) is mitigated by the fact that we are looking at the impact of a given level of competition on productivity growth.
} 
New firms undertake more innovation but there is no consistent sign on new firms in the growth equations. As we shall see below, this reflects the way that employment growth is modelled.

Table 6. Determinants of sales growth, employment growth treated as exogenous

\begin{tabular}{|c|c|c|c|c|c|c|c|c|}
\hline \multirow{2}{*}{ Dependent variable } & \multicolumn{2}{|c|}{$(1)$} & \multicolumn{2}{|c|}{ (2) } & \multicolumn{2}{|c|}{ (3) } & \multicolumn{2}{|c|}{ (4) } \\
\hline & \multicolumn{2}{|c|}{ Real sales growth } & \multicolumn{2}{|c|}{ Real sales growth } & \multicolumn{2}{|c|}{$\begin{array}{l}\text { Real sales growth } \\
\text { (old firms) }\end{array}$} & \multicolumn{2}{|c|}{$\begin{array}{l}\text { Real sales growth } \\
\text { (new firms) }\end{array}$} \\
\hline Estimation method & \multicolumn{2}{|c|}{ OLS } & \multicolumn{2}{|c|}{ GMM } & \multicolumn{2}{|c|}{ GMM } & \multicolumn{2}{|c|}{ GMM } \\
\hline Employment growth & \multicolumn{2}{|c|}{$\begin{array}{c}0.602 * * \\
(0.028)\end{array}$} & \multicolumn{2}{|c|}{$\begin{array}{l}0.530 * * \\
(0.036)\end{array}$} & \multicolumn{2}{|c|}{$\begin{array}{l}0.439 * * \\
(0.046)\end{array}$} & \multicolumn{2}{|c|}{$\begin{array}{l}0.619 * * \\
(0.055)\end{array}$} \\
\hline Innovation & \multicolumn{2}{|c|}{$\begin{array}{c}0.052 * * \\
(0.007)\end{array}$} & \multicolumn{2}{|c|}{$\begin{array}{c}0.181 * * \\
(0.038)\end{array}$} & \multicolumn{2}{|c|}{$\begin{array}{c}0.192 * * \\
(0.042)\end{array}$} & \multicolumn{2}{|c|}{$\begin{array}{l}0.121^{+} \\
(0.064)\end{array}$} \\
\hline $\begin{array}{l}\text { Number of competitors } \\
1-3 \text { competitors }\end{array}$ & \multicolumn{2}{|c|}{$\begin{array}{c}0.100 * * \\
(0.030) \\
0.041 \\
(0.025)\end{array}$} & \multicolumn{2}{|c|}{$\begin{array}{c}0.081 * * \\
(0.032) \\
0.045 \\
(0.027)\end{array}$} & \multicolumn{2}{|c|}{$\begin{array}{c}0.047 \\
(0.037) \\
0.001 \\
(0.032)\end{array}$} & \multicolumn{2}{|c|}{$\begin{array}{c}0.149 * * \\
(0.057) \\
0.104^{+} \\
(0.054)\end{array}$} \\
\hline $\begin{array}{l}\text { Tests of number of } \\
\text { competitors }\end{array}$ & Vs. 0 & vs. $>3$ & vs. 0 & vs. $>3$ & Vs. 0 & vs. $>3$ & Vs. 0 & vs. $>3$ \\
\hline $1-3$ vs. zero $1-3$ vs. $>3$ & $* *$ & $* *$ & $* *$ & 0 & $* *$ & 0 & $* *$ & 0 \\
\hline $\begin{array}{l}\text { Market power (10\% test) } \\
\text { Sales would fall a lot } \\
\text { Sales would fall slightly } \\
\text { No change in sales }\end{array}$ & \multicolumn{2}{|c|}{$\begin{array}{c}0.019 \\
(0.019) \\
0.087 * * \\
(0.018) \\
0.072 * * \\
(0.022)\end{array}$} & \multicolumn{2}{|c|}{$\begin{array}{c}0.003 \\
(0.021) \\
0.056^{* *} \\
(0.021) \\
0.051 * \\
(0.024)\end{array}$} & \multicolumn{2}{|c|}{$\begin{array}{l}-0.008 \\
(0.028) \\
0.061 * \\
(0.026) \\
0.068 * \\
(0.031)\end{array}$} & \multicolumn{2}{|c|}{$\begin{array}{c}0.018 \\
(0.029) \\
0.057 \\
(0.036) \\
0.025 \\
(0.036)\end{array}$} \\
\hline New firm & & $\begin{array}{l}08 \\
16)\end{array}$ & & & & & & \\
\hline Services & & & & & & & & $\begin{array}{l}21 \\
41)\end{array}$ \\
\hline Agriculture & & & & & & & & $\begin{array}{l}76 \\
40)\end{array}$ \\
\hline Big city & & & & 02 & & & & $\begin{array}{l}21 \\
22)\end{array}$ \\
\hline Excluded instruments & & & $\begin{array}{r}\text { Pres } \\
\text { innov }\end{array}$ & $\begin{array}{l}\text { are to } \\
\text { te, size }\end{array}$ & $\begin{array}{r}\text { Pres } \\
\text { innov }\end{array}$ & $\begin{array}{l}\text { ire to } \\
\text { e, size }\end{array}$ & $\begin{array}{r}\text { Pres } \\
\text { innov }\end{array}$ & $\begin{array}{l}\text { ire to } \\
\text { e, size }\end{array}$ \\
\hline $\begin{array}{l}\text { First-stage F-test of } \\
\text { excluded instruments }\end{array}$ & & & $\mathrm{F}(3,325$ & $=33.2$ & $\mathrm{~F}(3,157$ & $=26.0$ & $\mathrm{~F}(3,163$ & $=11.2$ \\
\hline $\begin{array}{l}\text { Test of overidentifying } \\
\text { restrictions (Hansen } J \text { ) }\end{array}$ & & & $\begin{array}{r}\chi^{2}(2 \\
\mathrm{p}-\mathrm{val}\end{array}$ & $\begin{array}{l}=1.80 \\
e=0.41\end{array}$ & $\begin{array}{r}\chi^{2}(2 \\
\mathrm{p}-\mathrm{val}\end{array}$ & $\begin{array}{l}=1.10 \\
=0.58\end{array}$ & $\begin{array}{r}\chi^{2}(2 \\
\mathrm{p}-\mathrm{val}\end{array}$ & $\begin{array}{l}=0.41 \\
=0.82\end{array}$ \\
\hline Number of observations & & & & & & & & 73 \\
\hline
\end{tabular}

Notes:

$={ }^{+}$sig. at $10 \%, *=$ sig. at $5 \% ; * *=$ sig. at $1 \%$.

Standard errors and test statistics are heteroskedastic-robust. 
The diagnostic tests of the instruments for innovation are quite satisfactory, with the F-tests of the excluded instruments in the first stage regression ranging from 11 (for new firms only) to over 30 (for the total sample). The overidentification tests are also comfortably passed in each specification, which indicates that it is correct to exclude the 'pressure' and size variables from the growth equation.

Since we cannot be fully confident that our estimation of the productivity growth equation has dealt satisfactorily with the endogeneity of employment growth, we experiment with a range of values of the employment growth elasticity and explore the implications for how the growth equation behaves. The results for coefficients ranging from 1 (which makes the growth equation a labour productivity growth equation) to a coefficient of 0.25 are shown in Table 7. The key competition results discussed in connection with Table 6 remain in place, which is reassuring.

This experiment provides some additional insight into forces behind the growth of new as compared with old firms. We have seen that new firms do significantly more innovation than do old ones. We note that, in the structural equation for growth in Table 7, as the coefficient on employment growth is reduced from one, the coefficient on new firms begins as negative and significant (as in the reduced form labour productivity growth equation), is insignificant when the coefficient on employment growth is 0.5 and becomes positive and significant when the coefficient is reduced to 0.25 .

How can we interpret this? Our prior is that new private firms get more of their growth from labour growth and less from capital deepening than is the case for old firms. In our augmented TFP-like growth equation we do not have capital growth, but instead we have our measure of innovation. Although some capital deepening will be captured in the innovation variable (specifically, the opening of a new plant) some will be in the productivity growth residual. When the employment growth elasticity is assumed to be large, then the rapid labour growth of new private firms explains a lot of sales growth and innovation explains some of what is attributable to capital growth. In this scenario, the dummy for new private firms takes on the character of a dummy for slow capital deepening and therefore attracts a negative coefficient. Conversely, when the coefficient on employment growth is constrained to be small ( 0.25 or indeed zero as in the column (1) of Table 4$)$, the rapid labour 
growth of the new private firms is allowed to explain little of their growth, with the consequence that the dummy for the new firms captures this instead and turns positive.

Table 7. Determinants of sales growth, imposed labour elasticity

\begin{tabular}{|c|c|c|c|c|c|c|c|c|}
\hline \multirow[b]{2}{*}{$\begin{array}{l}\text { Dependent variable } \\
\text { Sales growth with } \\
\text { imposed labour elasticity } \\
\text { of: }\end{array}$} & \multicolumn{2}{|c|}{ (1) } & \multicolumn{2}{|c|}{ (2) } & \multicolumn{2}{|c|}{ (3) } & \multicolumn{2}{|c|}{ (4) } \\
\hline & \multicolumn{2}{|c|}{1} & \multicolumn{2}{|c|}{0.75} & \multicolumn{2}{|c|}{0.5} & \multicolumn{2}{|c|}{0.25} \\
\hline Estimation method & \multicolumn{2}{|c|}{ GMM } & \multicolumn{2}{|c|}{ GMM } & \multicolumn{2}{|c|}{ GMM } & \multicolumn{2}{|c|}{ GMM } \\
\hline Innovation & \multicolumn{2}{|c|}{$\begin{array}{l}0.104 * * \\
(0.035)\end{array}$} & \multicolumn{2}{|c|}{$\begin{array}{l}0.145 * * \\
(0.034)\end{array}$} & \multicolumn{2}{|c|}{$\begin{array}{l}0.187 * * \\
(0.035)\end{array}$} & \multicolumn{2}{|c|}{$\begin{array}{l}0.228^{* * *} \\
(0.037)\end{array}$} \\
\hline $\begin{array}{l}\text { Number of competitors } \\
1-3 \text { competitors }\end{array}$ & \multicolumn{2}{|c|}{$\begin{array}{c}0.096 * * \\
(0.034) \\
0.054 \\
(0.029)\end{array}$} & \multicolumn{2}{|c|}{$\begin{array}{c}0.088 * * \\
(0.032) \\
0.050 \\
(0.027)\end{array}$} & \multicolumn{2}{|c|}{$\begin{array}{c}0.080 * * \\
(0.032) \\
0.045 \\
(0.027)\end{array}$} & \multicolumn{2}{|c|}{$\begin{array}{c}0.072 * \\
(0.033) \\
0.040 \\
(0.028)\end{array}$} \\
\hline $\begin{array}{l}\text { Tests of number of } \\
\text { competitors }\end{array}$ & vs. 0 & vs. $>3$ & Vs. 0 & vs. $>3$ & Vs. 0 & vs. $>3$ & vs. 0 & vs. $>3$ \\
\hline $1-3$ vs. zero $1-3$ vs. $>3$ & $* *$ & & $* *$ & & $* *$ & 0 & $* *$ & 0 \\
\hline \multirow{2}{*}{$\begin{array}{l}\text { Market power (10\% test) } \\
\text { Sales would fall a lot }\end{array}$} & \multirow{2}{*}{\multicolumn{2}{|c|}{$\begin{array}{c}0.005 \\
(0.021)\end{array}$}} & \multirow{2}{*}{\multicolumn{2}{|c|}{$\begin{array}{c}0.003 \\
(0.020)\end{array}$}} & \multirow{2}{*}{\multicolumn{2}{|c|}{$\begin{array}{c}0.002 \\
(0.021)\end{array}$}} & \multirow{2}{*}{\multicolumn{2}{|c|}{$\begin{array}{c}0.002 \\
(0.022)\end{array}$}} \\
\hline & & & & & & & & \\
\hline Sales would fall slightly & \multicolumn{2}{|c|}{$\begin{array}{c}0.054 * * \\
(0.021)\end{array}$} & \multicolumn{2}{|c|}{$\begin{array}{l}0.055^{* *} \\
(0.021)\end{array}$} & \multicolumn{2}{|c|}{$\begin{array}{c}0.056^{* *} \\
(0.021)\end{array}$} & \multicolumn{2}{|c|}{$\begin{array}{c}0.056^{* *} \\
(0.023)\end{array}$} \\
\hline No change in sales & \multicolumn{2}{|c|}{$\begin{array}{c}0.029 \\
(0.025)\end{array}$} & & & & & & \\
\hline New firm & $\begin{aligned}-0.0 & \\
(0 . & \end{aligned}$ & $\begin{array}{l}91 * * \\
16)\end{array}$ & $\begin{aligned} &-0 . \\
&(0\end{aligned}$ & $\begin{array}{l}12 * * \\
15)\end{array}$ & & & & $\begin{array}{l}6 * * \\
17)\end{array}$ \\
\hline Services & & $\begin{array}{l}19 \\
24)\end{array}$ & & $\begin{array}{l}50 * \\
24)\end{array}$ & & $\begin{array}{l}0 * * \\
25)\end{array}$ & & $\begin{array}{l}1 * * \\
28)\end{array}$ \\
\hline Agriculture & & 69* & & $\begin{array}{l}3 * * \\
31)\end{array}$ & & $\begin{array}{l}6 * \\
31)\end{array}$ & & $\begin{array}{l}9 * * \\
32)\end{array}$ \\
\hline Big city & & 20 & & $\begin{array}{l}10 \\
18)\end{array}$ & & & & $\begin{array}{l}08 \\
19)\end{array}$ \\
\hline Country dummies & & es & & & & & & \\
\hline Excluded instruments & $\begin{array}{r}\text { Pres } \\
\text { innov }\end{array}$ & $\begin{array}{l}\text { ure to } \\
\text { te, size }\end{array}$ & $\begin{aligned} \text { Pres } \\
\text { innov }\end{aligned}$ & $\begin{array}{l}\text { are to } \\
\text { te, size }\end{array}$ & $\begin{array}{l}\text { Pres } \\
\text { innov }\end{array}$ & $\begin{array}{l}\text { Ire to } \\
\text { e, size }\end{array}$ & $\begin{aligned} \text { Pres } \\
\text { innor }\end{aligned}$ & $\begin{array}{l}\text { re to } \\
\text { e, size }\end{array}$ \\
\hline $\begin{array}{l}\text { Test of overidentifying } \\
\text { restrictions (Hansen J) }\end{array}$ & $\begin{array}{r}\chi^{2}(2 \\
\text { p-val }\end{array}$ & $\begin{array}{l}=0.57 \\
e=0.75\end{array}$ & $\begin{array}{r}\chi^{2}(2 \\
\text { p-val }\end{array}$ & $\begin{array}{l}=1.19 \\
e=0.55\end{array}$ & $\begin{array}{r}\chi^{2}(2 \\
\mathrm{p}-\mathrm{val}\end{array}$ & $\begin{array}{l}=87 \\
=0.39\end{array}$ & $\begin{array}{r}\chi^{2}(2 \\
\mathrm{p}-\mathrm{val}\end{array}$ & $\begin{array}{l}2.41 \\
=0.30\end{array}$ \\
\hline
\end{tabular}

Notes:

* = significant at 5\%; ** = significant at $1 \%$; heteroskedastic-robust standard errors in (); number of observations $=3288$.

First-stage regression statistic (all equations): heteroskedastic-robust $\mathrm{F}(3,3251)=38.7$.

Heteroskedasticity-robust endogeneity tests: (1) vs. (2), $\chi^{2}(2)=19.8$, p-value $=0.00$, OLS rejected; (1) vs. (4), $\chi^{2}(1)=14.2, p$-value $=0.00$, OLS rejected.

\section{The interaction between managerial motivation and resources}

In this section we explore the interaction between the number of competitors faced by a firm and its market power as measured by the freedom to raise prices. We suggested above that the former might work primarily through influencing the motivation of managers, and the 
latter through influencing the resources over which they have discretionary control. Table 8 provides evidence which clearly corroborates this suggestion. It reports the results of variants of the regression for innovation. Column (1) repeats for comparative purposes the basic equation reported in Table 5, with the minor modification that the market power variable is entered in cardinal rather than categorical form. This is motivated by the clarity it lends to the experiment we focus on here. Columns (2) and (3) exclude respectively the market power $(10 \%$ test) and number of competitors variable. This also has almost no effect on the results, which strengthens our belief that these measures may be capturing distinct aspects of market power rather than being alternative imperfect measures of the same phenomenon. The same finding holds true in the growth equation, although we do not report this result explicitly.

Column (4) reports the result of interacting the number of competitors with the market power $(10 \%$ test) variable. The results are striking. Firms facing no competitors do no more innovation when they have market power than when they do not. Firms with 1-3 competitors, on the other hand, do more innovation when they have market power than when they do not. So do firms with more than three competitors. Both the latter two coefficients are significantly different from the first coefficient at $10 \%$ levels, though they are not significantly different from each other. 
Table 8. Determinants of innovation

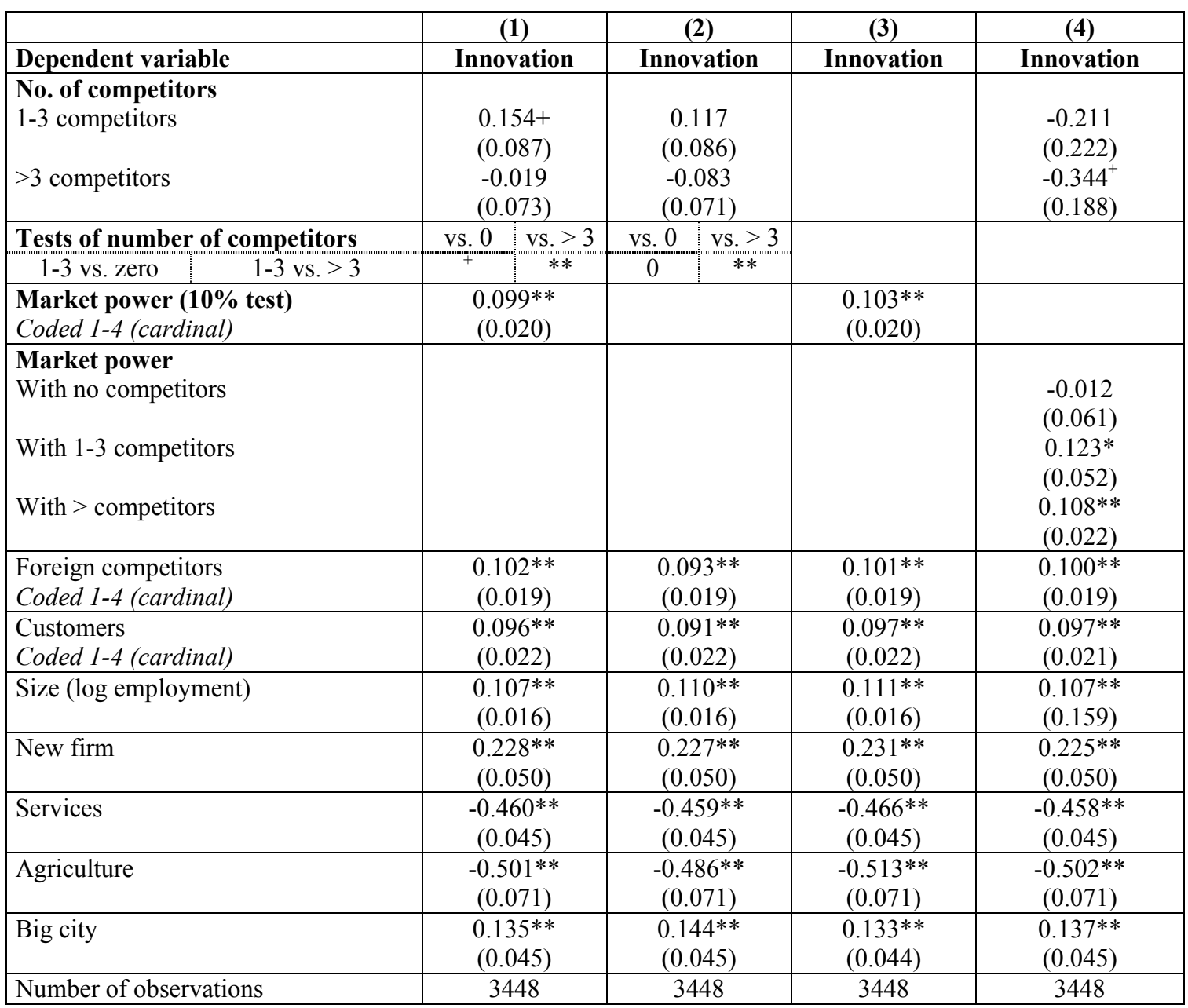

Notes:

$+=$ sig. at $10 \%, *=\operatorname{sig}$. at $5 \% ; * *=$ sig. at $1 \%$; heteroskedastic-robust standard errors in () .

In the growth equations, by contrast, there is no significant interaction between the number of competitors and the freedom to raise prices, though once again we do not report these results explicitly.

These results provide suggestive, though not conclusive, evidence that our measures of numbers of competitors and of the freedom to raise prices are indeed measuring distinct facets of a firm's market power, rather than being imperfect proxies for one single phenomenon. It seems plausible to suggest that the former represents the motivation of managers while the latter captures the resources over which they have discretionary control. Pursuing this hypothesis further seems to us a fruitful subject for further research. 


\section{Concluding remarks}

The chief finding of this study is the power of competition in influencing innovation and growth. In the innovation equation, the presence of some market power together with competitive pressure from foreign suppliers, strongly and robustly enhances performance, though in ways that differ interestingly and intuitively between old and new firms. Furthermore, it appears that the presence of at least some rivalry in the market is important not just in its own right but because it ensures that the resources available to a firm from any market power it enjoys are efficiently used. In the productivity growth equation (where we control for innovation as well as for employment growth), innovation matters strongly for growth but there is an additional effect of competition, indicating that intense rivalry in the product market raises residual productivity growth. The effect is stronger for new firms than for old ones, for whom the competition impact works more strongly through innovation. There is also some evidence that the effect is stronger for limited rivalry (one to three competitors) than for more than three competitors - the inverse- $U$ relation. The difference is not consistently significant at conventional levels in the structural equations, though it is significant in all the reduced-form specifications. This means that we can be more confident that an inverse- $U$ relation of some sort characterizes the link between competition and growth than about the channels through which such a relation might operate.

Although we have made a start in examining the channels through which these competitive pressures work, notably by distinguishing between factors influencing managerial incentives and those influencing the resources under managers' discretionary control, it is not possible on the evidence we have to distinguish more precisely between alternative hypotheses about the mechanisms at work. However, these findings are certainly consistent with the presence of a Schumpeterian-type competitive process, albeit one accompanied by considerable disruption and turbulence (see Carlin, Haskel and Seabright, 2001). Consistently also with the findings of Bresnahan and Reiss (1991), this evidence suggests that it is the presence of a minimum number of seriously competing firms that generates competitive conduct. And retained profits - in the presence of competitive pressure - appear also to be important for financing the restructuring that helps firms to succeed.

We have also been able to show that new private firms are more heavily engaged in innovation than are firms that pre-existed the reforms. Light was thrown on the paradox of 
the significantly better performance of new firms on innovation but their apparently weaker labour productivity growth performance by experimenting with different elasticities on employment growth. New firms appear to rely systematically more on labour than on capitaldeepening growth in expanding their activities. We have also suggested how endogeneity in new firms' perceptions of competitors in their niche may account for the negative sign on the number of competitors in the innovation equation.

Turning to policy implications, our findings strongly reinforce the message that unchallenged monopoly is a drain on dynamism. It is certainly more important to ensure that monopolists face at least some challenge than to try refereeing the necessarily confused process of rivalry among the few. It is true that at the same time as the importance of competition is becoming more apparent, so are the difficulties in the way of bringing about such a process effectively, especially in countries trying to establish market systems from scratch (see Fingleton, Fox, Neven \& Seabright, 1996). But our results help to illuminate the ingredients needed for the competitive process to work. Not only must there be a market structure in which firms face rivalry but also: removal of the obstacles facing new entrants and financial systems that can support major investments in restructuring.

Finally, our results strongly support the value of using measures of market power that correspond to the perceptions of individual firms as to the competitive pressures they face. These are an important supplement to more conventional measures, such as shares of markets based on conventional industrial classifications. These can help not just in illuminating the overall pressures faced by firms but also the way in which different constraints on managerial decision-making interact. 


\section{References}

P. Aghion and P. Howitt (1998), Endogenous Growth Theory, MIT Press, Cambridge, MA.

P. Aghion, N. Bloom, R. Blundell, R. Griffith, and P. Howitt (2002): 'Competition and Innovation: An Inverted-U Relationship', IFS Working Paper 0204

http://www.ifs.org.uk/workingpapers/wp0204.pdf.

P. Aghion, M. Dewatripont, and P. Rey (1999), 'Competition, Financial Discipline, and Growth,' Review of Economic Studies, Vol. 66, pp. 825-852.

P. Aghion, C. Harris, P. Howitt, and J.Vickers (2001), 'Competition, Imitation and Growth with Step-by-Step Innovation', Review of Economic Studies., Vol. 68, No. 3, 467-492.

P. Aghion and R. Griffith (2004 forthcoming). Competition and Growth, MIT Press, Cambridge, MA

J. Angrist and A. Krueger (1991), 'Does Compulsory School Attendance Affect Schooling and Earnings?', Quarterly Journal of Economics, Vol. 106, pp. 979-1014.

M. N. Baily, and H.Gersbach (1995), 'Efficiency in Manufacturing and the Need for Global Competition,' Brookings Papers on Economic Activity: Microeconomics, pp. 307-347.

C.J. Baum, S. Stillman and M. Schaffer (2003), 'Instrumental Variables and GMM:

Estimation and Testing', The Stata Journal, Vol. 3, No. 1, pp. 1-31.

R. Blundell, R. Griffith and J. Van Reenen (1999), 'Market Share, Market Value and Innovation in a Panel of British Manufacturing Firms', Review of Economic Studies, Vol. 66, pp. 529-554.

T. Bresnahan and P. Reiss. (1991). 'Entry and competition in concentrated markets', Journal of Political Economy, Vol. 99, No. 5, pp. 977-1009.

W. Carlin, J. Haskel and P. Seabright. (2001). 'Understanding "the essential fact about capitalism”: markets, competition and creative destruction', National Institute Economic Review. January.

W. Carlin. S. Fries, M. Schaffer \& P. Seabright (2001): 'Competition and Enterprise Performance in Transition Economies: Evidence from a Cross-country Survey', CEPR discussion paper no. 2840.

I. Chalmers and D.G. Altman (eds.) (1995). Systematic Reviews London: BMJ Publishing Group.

S. Djankov and V.-G. Kreacic (1998), 'Restructuring of manufacturing firms in Georgia: four case studies and a survey’, Working Paper. 
S. Djankov and P. Murrell (2002). 'Enterprise restructuring in transition: a quantitative survey', Journal of Economic Literature, Vol. 40, No. 3, pp.739-792.

J. Dutta \& P. Seabright (2002): 'Competition and Economic Growth', University of Birmingham, mimeo.

J. Fingleton, E. Fox, D. Neven and P. Seabright (1996): Competition Policy and the Transformation of Central Europe, London, Centre for Economic Policy Research.

I. Grosfeld, and T. Tressel (2002), 'Competition, Corporate Governance: Substitutes or Complements? Evidence from the Warsaw Stock Exchange', Economics of Transition, Vol. 10, No. 3.

R. E. Hall, (1988), 'The Relation between Price and Marginal cost in U.S. Industry', Journal of Political Economy, Vol. 96, No. 5, pp. 921-947.

J. Hausman, G. Leonard and J.D. Zona (1994): 'Competitive Analysis with Differentiated Products', Annales d'Economie et de Statistique, Vol. 34, pp. 159-180.

W.A. Fuller, (1977), "Some Properties of a Modification of the Limited Information Estimator", Econometrica, Vol. 45, pp. 939-954.

P. Kattuman, and R. Domanski, (1997) 'Industrial concentration under shock therapy: Poland in early transition years', ESRC Centre for Business Research, Cambridge University, Working Paper No. 76.

J. Konings (1998), 'Firm performance in Bulgaria and Estonia: the effects of competitive pressure, financial pressure and disorganization', The Davidson Institute Working Paper Series, No. 185.

D. Neven, R. Nuttall \& P. Seabright (1993): Merger in Daylight: the Economics and Politics of European Merger Control, London, Centre for Economic Policy Research.

S. Nickell (1996). 'Competition and corporate performance', Journal of Political Economy, Vol. 104, August, pp. 724-46.

J. A. Schumpeter (1943) Capitalism, Socialism and Democracy. London, Allen and Unwin, reprinted 1976. 


\section{Data Appendix: Survey method}

The survey instrument was developed by the staff of the EBRD and World Bank and the authors of this paper. The 1996 survey by Brunetti et al.on behalf of the World Bank provided a basis for this instrument. The sampling frame was designed to be broadly representative of the population of the firms according to their economic significance, sector, size and geographical location within each country. The sectoral composition of the total sample in each country in terms of industry versus services was determined by their relative contribution to GDP after allowing for certain excluded sectors. Firms that operated in sectors subject to government price regulation and prudential supervisions, such as banking, electric power, rail transport, water and wastewater were excluded from the sample.

Enterprises eligible for the 1999 BEEPS were therefore in the following sectors:

\section{Industry}

1. Agriculture, hunting and forestry (ISIC Sections A: 1-2, B: 5)

2. Mining and quarrying (ISIC Section C: $10-14$ )

3. Construction (ISIC Section F: 45)

4. Manufacturing (ISIC Section D: $15-37$ )

\section{Services}

5. Transportation (ISIC Section I: $60-62$ )

6. Wholesale and retail trade and repairs (ISIC Section G: $50-52$ )

7. Real estate and business services (ISIC Section K: $70-74$ )

8. Financial services (ISIC Section J: 67)

9. Hotels, restaurants and other personal services (ISIC Sections H: 55, I:63 )

10. Other community, social and personal services (ISIC Section M:80, N: 85, O: 91 93 and 93)

The International Standard Industrial Classification (ISIC) codes for each sector are reported parenthetically.

Within sectors, the sample was designed to be as representative as possible of the population of firms subject to various minimum quotas for the total sample in each country. 
This approach sought to achieve a representative cross-section of firms while ensuring sufficient weight in the tails of the distribution of firms for key control parameters (size, geographical location, exports, and ownership). The minimum quotas of the samples for each country were:

1. At least 15 per cent of the total sample should be small in size ( 2 to 49 employees) and 15 per cent large (200 to 9,999 employees) Firms with only one employee and 10,000 or more employees were excluded from the sample.

2. At least 15 per cent of the firms should have foreign control and 15 per cent state control, where control is defined as an ownership share of more than 50 per cent.

3. At least 15 per cent of the firms should be exporters, meaning that at least 20 per cent of their total sales are from exports.

4. At least 15 per cent of the firms should be located in a small city (population under $50,000)$ or countryside.

The BEEPS was implemented in 24 of the 27 countries of Central and Eastern Europe and the former Soviet Union. For analytical purposes, the Federation of Bosnia and Herzegovina and Republika Srpska are treated separately. The survey was not implemented in FR Yugoslavia, Tajikistan and Turkmenistan because AC Nielsen did not have the capacity to implement the survey in these countries, in some cases due to the security situation.

AC Nielsen implemented the survey on behalf of the EBRD and World Bank and was selected through a competitive tendering process. AC Nielsen follows the ICC/ESOMAR International Code of Marketing and Social Research Practice (www.esomar.org, click on codes and guidelines), including those pertaining to the rights of respondents. These rights provide for the confidentiality and anonymity of the respondents. The interviewers working on behalf of AC Nielsen assured the survey respondents that their identities would not be disclosed to either the sponsoring institutions or government authorities and that their anonymity would be protected. 


\section{DAVIDSON INSTITUTE WORKING PAPER SERIES - Most Recent Papers}

The entire Working Paper Series may be downloaded free of charge at: www.wdi.bus.umich.edu

CURRENT AS OF 3/15/04

\begin{tabular}{|c|c|c|}
\hline Publication & Authors & Date \\
\hline $\begin{array}{l}\text { No. 670: A minimum of rivalry: evidence from transition economies on } \\
\text { the importance of competition for innovation and growth }\end{array}$ & $\begin{array}{l}\text { Wendy Carlin, Mark Schaffer } \\
\text { and Paul Seabright }\end{array}$ & Mar. 2004 \\
\hline No. 669: Dual Track Liberalization: With and Without Losers & $\begin{array}{l}\text { Jiahua Che and Giovanni } \\
\text { Facchini }\end{array}$ & Mar. 2004 \\
\hline $\begin{array}{l}\text { No. 668: Enterprise Restructuring and Firm Performance: } \\
\text { A Comparison of Rural and Urban Enterprises in Jiangsu Province }\end{array}$ & $\begin{array}{l}\text { Xiao-yuan Dong, Louis } \\
\text { Putterman and Bulent Unel }\end{array}$ & Mar. 2004 \\
\hline $\begin{array}{l}\text { No. 667: A Tale of Two Provinces: The Institutional Environment and } \\
\text { Foreign Ownership in China }\end{array}$ & Yasheng Huang and Wenhua Di & Mar. 2004 \\
\hline $\begin{array}{l}\text { No. 666: Ownership Characteristics and Access to Finance: } \\
\text { Evidence from a Survey of Large Privatised Companies in Hungary } \\
\text { and Poland }\end{array}$ & $\begin{array}{l}\text { Natalia Isachenkova and Tomasz } \\
\text { Mickiewicz }\end{array}$ & Mar. 2004 \\
\hline $\begin{array}{l}\text { No. 665: Testing Creditor Moral Hazard in Sovereign Bond Markets: } \\
\text { A Unified Theoretical Approach and Empirical Evidence }\end{array}$ & $\begin{array}{l}\text { Ayşe Y. Evrensel and Ali M. } \\
\text { Kutan }\end{array}$ & Mar. 2004 \\
\hline $\begin{array}{l}\text { No. 664: Assessing Equilibrium Exchange Rates in CEE Acceding } \\
\text { Countries: Can We Have DEER with BEER without FEER? }\end{array}$ & Balázs Égert & Feb. 2004 \\
\hline $\begin{array}{l}\text { No. 663: Modelling stock returns in the G-7 and in selected CEE } \\
\text { economies: A non-linear GARCH approach }\end{array}$ & Balázs Égert and Yosra Koubaa & Feb. 2004 \\
\hline $\begin{array}{l}\text { No. 662: Institutional Change and Product Composition: Does the Initial } \\
\text { Quality of Institutions Matter? }\end{array}$ & $\begin{array}{l}\text { Johannes Moenius and Daniel } \\
\text { Berkowitz }\end{array}$ & Feb. 2004 \\
\hline No. 661: Dual track liberalization: With and without losers & $\begin{array}{l}\text { Jiahua Che and Giovanni } \\
\text { Facchini }\end{array}$ & Feb. 2004 \\
\hline $\begin{array}{l}\text { No. 660: Who Is in Favor of Enlargement? Determinants of Support for } \\
\text { EU Membership in the Candidate Countries' Referenda }\end{array}$ & Orla Doyle and Jan Fidrmuc & Feb. 2004 \\
\hline $\begin{array}{l}\text { No. 659: Creditor Moral Hazard in Equity Markets: } \\
\text { A Theoretical Framework and Evidence from Indonesia and Korea }\end{array}$ & $\begin{array}{l}\text { Ayşe Y. Evrensel and Ali M. } \\
\text { Kutan }\end{array}$ & Feb. 2004 \\
\hline No. 658: Worsening of the Asian Financial Crisis: Who is to Blame? & $\begin{array}{l}\text { Brasukra G. Sudjana and Ali M. } \\
\text { Kutan }\end{array}$ & Feb. 2004 \\
\hline $\begin{array}{l}\text { No. 657: European Integration, Productivity Growth and Real } \\
\text { Convergence }\end{array}$ & Taner M. Yigit and Ali M. Kutan & Feb. 2004 \\
\hline $\begin{array}{l}\text { No. 656: The Impact of News, Oil Prices, and Global Market } \\
\text { Developments on Russian Financial Markets }\end{array}$ & Bernd Hayo and Ali M. Kutan & Feb. 2004 \\
\hline No. 655: Politics and Economic Reform in Malaysia & Bryan K. Ritchie & Feb. 2004 \\
\hline No. 654: The Evolution of Income Inequality in Rural China & $\begin{array}{l}\text { Dwayne Benjamin, Loren Brandt } \\
\text { and John Giles }\end{array}$ & Feb. 2004 \\
\hline $\begin{array}{l}\text { No. 653: The Sources of Real Exchange Fluctuations in } \\
\text { Developing Countries : an Econometric Investigation }\end{array}$ & Imed Drine and Christophe Rault & Feb. 2004 \\
\hline $\begin{array}{l}\text { No. 652: Ownership, Control and Corporate Performance After } \\
\text { Large-Scale Privatization }\end{array}$ & $\begin{array}{l}\text { Jan Hanousek, Evzen Kocenda } \\
\text { and Jan Svejnar }\end{array}$ & Feb. 2004 \\
\hline $\begin{array}{l}\text { No. 651: Czech Social Reform/Non-reform: Routes, Actors and } \\
\text { Problems }\end{array}$ & Jiri Vecernik & Feb. 2004 \\
\hline $\begin{array}{l}\text { No. 650: Financial Integration, Exchange Rate Regimes in CEECs, } \\
\text { and Joining the EMU: Just Do It... }\end{array}$ & Maurel Mathilde & Feb. 2004 \\
\hline $\begin{array}{l}\text { No. 649: Corporate Investments, Liquidity and Bank Financing: } \\
\text { Empirical Evidence from an Emerging Market }\end{array}$ & Arun Khanna & Feb. 2004 \\
\hline $\begin{array}{l}\text { No. 648: Financial Constraints in Investment - Foreign Versus } \\
\text { Domestic Firms. Panel Data Results From Estonia, 1995-1999. }\end{array}$ & $\begin{array}{l}\text { Tomasz Mickiewicz, Kate Bishop } \\
\text { and Urmas Varblane }\end{array}$ & Feb. 2004 \\
\hline $\begin{array}{l}\text { No. 647: Legal Minimum Wages and the Wages of Formal and Informal } \\
\text { Sector Workers in Costa Rica }\end{array}$ & $\begin{array}{l}\text { T. H. Gindling and Katherine } \\
\text { Terrell }\end{array}$ & Feb. 2004 \\
\hline $\begin{array}{l}\text { No. 646: Employment Expectations and Gross Flows by Type of Work } \\
\text { Contract }\end{array}$ & $\begin{array}{l}\text { Catalina Amuedo-Dorantes and } \\
\text { Miguel Á. Malo }\end{array}$ & Jan. 2004 \\
\hline $\begin{array}{l}\text { No. 645: Transition on the Shop Floor - The Restructuring of a Weaving } \\
\text { Mill, Hungary 1988-97 }\end{array}$ & János Köllö & Jan. 2004 \\
\hline
\end{tabular}

